\title{
Activation of Propargyl Alcohols by TpRu Complexes Bearing a Bidentate NHC Ligand
}

\author{
Manuel Jiménez-Tenorio,* M. Carmen Puerta,* and Pedro Valerga \\ Departamento de Ciencia de los Materiales e Ingeniería Metalúrgica y Química Inorgánica-INBIO, Facultad de Ciencias, \\ Universidad de Cádiz, 11510 Puerto Real, Cádiz, Spain
}

\section{Supporting Information}

ABSTRACT: The complex [TpRuCl(COD) $]$ reacts with $\mathbf{L} \cdot \mathrm{Ag}_{2} \mathrm{Cl}_{2}(\mathbf{L}=$ bis $(3-$ methylimidazol-2-ylidene)) in dichloroethane at $120{ }^{\circ} \mathrm{C}$ for a period of $20 \mathrm{~h}$, furnishing the bis(carbene) derivative $[\mathrm{TpRuCl}(\mathrm{L})](\mathbf{1})$. This compound reacts with $\mathrm{NaBAr}_{4}^{\prime}$ in $\mathrm{FPh}$ under dinitrogen to yield the cationic dinitrogen complexes $\left[\mathrm{TpRu}\left(\mathrm{N}_{2}\right)(\mathbf{L})\right]\left[\mathrm{BAr}_{4}^{\prime}\right]\left(\mathbf{2}^{\prime}\right)$ and $\left[\{\mathrm{TpRu}(\mathbf{L})\}\left(\mu-\mathrm{N}_{2}\right)\right]\left[\mathrm{BAr}_{4}^{\prime}\right]_{2}(\mathbf{2})$. The terminal dinitrogen complex $\mathbf{2}^{\prime}$ is labile and spontaneously converts into $\mathbf{2}$, which was structurally characterized. The reaction of 2 with $\mathrm{CO}$ is slow and affords $[\mathrm{TpRu}(\mathrm{CO})(\mathrm{L})]\left[\mathrm{BAr}_{4}^{\prime}\right]$ (3). The kinetics of the substitution of coordinated dinitrogen in 2 by $\mathrm{CD}_{3} \mathrm{CN}$ has been studied. The value of $25 \pm$ $4 \mathrm{kcal} \mathrm{mol}^{-1}$ determined for $\Delta G^{\ddagger}{ }_{298}$ for the substitution reaction is consistent

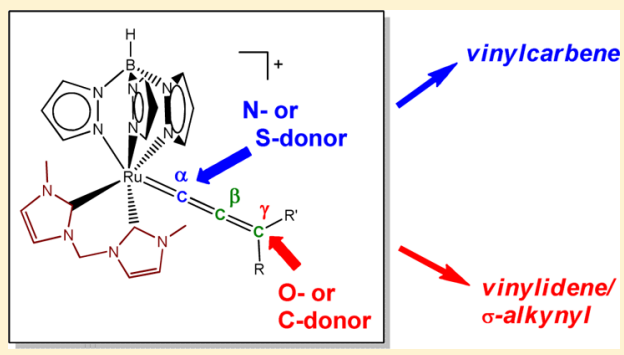
with the observation that the dinitrogen ligand is strongly bound to ruthenium in 2. Complex 1 reacts with propargyl alcohols $\mathrm{HC} \equiv \mathrm{CC}(\mathrm{OH}) \mathrm{RR}^{\prime}\left(\mathrm{RR}^{\prime}=\mathrm{Me}_{2},\left(\mathrm{CH}_{2}\right)_{5}, \mathrm{MePh}, \mathrm{HPh}\right)$ and $\mathrm{NaBPh}_{4}$ in $\mathrm{MeOH}$ at $50-60{ }^{\circ} \mathrm{C}$, yielding the corresponding $\gamma$-methoxyvinylidene complexes $\left[\mathrm{TpRu}=\mathrm{C}=\mathrm{CHC}(\mathrm{OMe}) \mathrm{RR}^{\prime}(\mathbf{L})\right]\left[\mathrm{BPh}_{4}\right]\left(\mathrm{RR}^{\prime}=\mathrm{Me}_{2}(\mathbf{4 a}),\left(\mathrm{CH}_{2}\right)_{5}(\mathbf{4 b}), \mathrm{MePh}(\mathbf{4 c}), \mathrm{HPh}\right.$ (4d)). The reaction of $\mathbf{1}$ with $\mathrm{HC} \equiv \mathrm{CCH}_{2} \mathrm{OH}$ under the same conditions led to the $\gamma$-hydroxyvinylidene derivative [TpRu= $\left.\mathrm{C}=\mathrm{CHCH}_{2} \mathrm{OH}(\mathrm{L})\right]\left[\mathrm{BPh}_{4}\right](\mathbf{5})$, whereas the reaction with $\mathrm{HC} \equiv \mathrm{CC}(\mathrm{OH}) \mathrm{Ph}_{2}$ resulted in the formation of the deep purple allenylidene complex $\left[\mathrm{TpRu}=\mathrm{C}=\mathrm{C}=\mathrm{CPh}_{2}(\mathrm{~L})\right]\left[\mathrm{BPh}_{4}\right](6)$. A series of $\mathrm{N}$ - and $\mathrm{S}$-donor molecules such as pyrazole, piperidine, 2-pyridinethiol, and 1,3-benzenedithiol add to the $\mathrm{C}_{\alpha}$ atom of the allenylidene ligand in 6 to yield the corresponding diphenylvinylcarbene species $\left[\mathrm{TpRu}=\mathrm{C}(\mathrm{X}) \mathrm{CH}=\mathrm{CPh}_{2}(\mathrm{~L})\right]\left[\mathrm{BPh}_{4}\right]\left(\mathrm{X}=\mathrm{C}_{3} \mathrm{H}_{3} \mathrm{~N}_{2}(7), \mathrm{N}\left(\mathrm{CH}_{2}\right)_{4} \mathrm{CH}_{2}(\mathbf{8}), \mathrm{SC}_{5} \mathrm{H}_{4} \mathrm{~N}(\mathbf{9})\right.$, $\mathrm{SC}_{6} \mathrm{H}_{4} \mathrm{SH}(\mathbf{1 0})$ ), of which compound 7 was structurally characterized. The reaction of 6 with $\mathrm{KOBu}^{\mathrm{t}}$ in acetone produced the neutral $\sigma$-alkynyl derivative $\left[\mathrm{TpRuC} \equiv \mathrm{CC}\left(\mathrm{CH}_{2} \mathrm{COCH}_{3}\right) \mathrm{Ph}_{2}(\mathbf{L})\right](\mathbf{1 1})$, resulting from the addition of acetone enolate to the $\mathrm{C}_{\gamma}$ of the allenylidene ligand.

\section{INTRODUCTION}

The activation of propargylic alcohols is the most general and direct access to allenylidene complexes, which in turn are considered key intermediates in selective catalytic transformations of these molecules. ${ }^{1,2}$ Nishibayashi and co-workers have developed a procedure for the ruthenium-catalyzed propargylic substitution of propargylic alcohols with a variety of nucleophiles. ${ }^{3-5}$ The proposed mechanism for the catalytic cycle (Scheme 1) involves the formation of a hydroxyvinylidene complex, which is transformed into allenylidene upon spontaneous dehydration. Then, the nucleophile adds to the $\mathrm{C}_{\gamma}$ of the allenylidene ligand, furnishing a new vinylidene species, which rearranges to the corresponding $\pi$-alkyne complex. The target substituted alkyne is released, and the active catalyst starts another cycle by coordination of another propargyl alcohol molecule. ${ }^{1,3,4 \mathrm{~b}}$

The most successful catalyst precursor for this process is the diruthenium(III,III) complex $\left[\{\mathrm{Cp} * \mathrm{RuCl}\}_{2}(\mu \text {-SMe })_{2}\right]^{3,4}$ The main substrates are propargyl alcohols bearing a terminal alkyne group, given the fact that the reaction proceeds via an allenylidene complex. However, slight modifications in the catalyst allow its use with internal alkynes as well. ${ }^{4 a}$ Enantioselective propargylic substitution reactions, with an observed enantiomeric excess in the range $68-94 \%$, have been carried out using the catalyst $\left[\{\mathrm{Cp} * \mathrm{RuCl}\}_{2}(\mu \text {-SR* })_{2}\right]$, which incorporates chiral thiolate ligands derived from (R)-1-(1-naphthyl)ethanethiol., ${ }^{2,5}$ Some mononuclear ruthenium complexes, such as $[\mathrm{CpRuCl}-$ $(\mathrm{COD})], \quad\left[\mathrm{CpRuCl}\left(\mathrm{PPh}_{3}\right)_{2}\right]$, and $\left[\mathrm{Ru}\left(\eta^{3}-2-\mathrm{C}_{3} \mathrm{H}_{4} \mathrm{Me}\right)(\mathrm{CO})-\right.$ $(\mathrm{dppf})]\left[\mathrm{SbF}_{6}\right]\left(\mathrm{dppf}=1,1^{\prime}\right.$-bis (diphenylphosphino)ferrocene), ${ }^{6,7}$ have also been successfully used as catalysts in propargylic substitution reactions. The relevance of ruthenium allenylidene complexes as key intermediates for propargylic substitution reactions has prompted many studies on the reactivity of allenylidene ligands attached to different ruthenium fragments. ${ }^{8-10}$ Many of these studies have focused on the factors controlling the selectivity of the addition of nucleophiles to either the $\mathrm{C}_{\alpha}$ or $\mathrm{C}_{\gamma}$ of the allenylidene ligand. ${ }^{11-13}$ Thus, the electronic and steric properties of the metal fragment and the allenylidene substituents control the regioselectivity. On the other hand, whereas the $\alpha$ - and $\gamma$-carbons are electrophilic centers, the $\beta$-carbon exhibits a nucleophilic character, and protonation at this position leads to vinyl-carbyne species. ${ }^{14,15}$ Our research group has broad experience with the chemistry of allenylidene complexes of

Received: November 20, 2015

Published: January 29, 2016 
Scheme 1. Proposed Mechanism for Ru-Catalyzed Propargylic Substitution

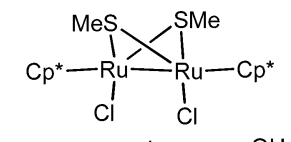

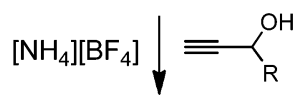

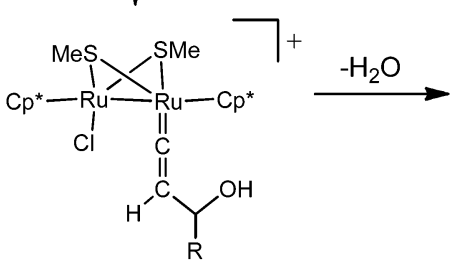<smiles>[R]C(C#C)OC[C@@H]1[C@@H]2CC2C1(C)C</smiles>

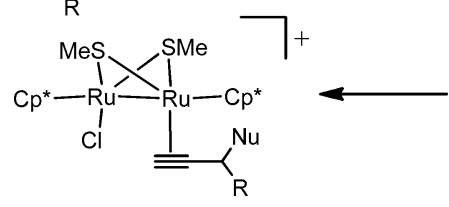

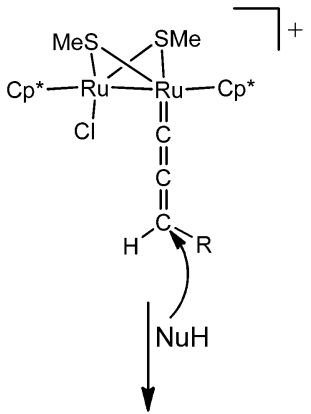

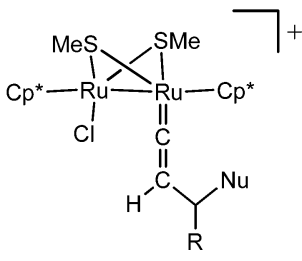

ruthenium bearing monodentate, bidentate, and hemilabile phosphine ligands. ${ }^{13,15,16}$ The electron richness of the metal center is tuned not only by the steric and electronic properties of the phosphine substituents but also by the nature of other supporting ligands such as hydrotris(pyrazolyl)borate $(\mathrm{Tp}),{ }^{16,17}$ $\mathrm{Cp},{ }^{11,17 c, 18} \mathrm{Cp}^{* 13,15,16}$ and indenyl. ${ }^{19}$ Thus, the fragments $\left\{\left[\mathrm{Cp} * \mathrm{Ru}\left(\mathrm{PR}_{3}\right)_{2}\right]^{+}\right\}\left(\mathrm{PR}_{3}=\mathrm{PEt}_{3}, \mathrm{PMe}^{\mathrm{i}} \mathrm{Pr}_{2}\right)$ and $\left\{[\mathrm{Cp} * \mathrm{Ru}(\text { dippe })]^{+}\right\}$ (dippe $=1,2$-bis (diisopropylphosphino)ethane) are electron rich, ${ }^{20}$ and nucleophilic addition reactions to the allenylidene ligand take place at the $\gamma$-carbon, yielding vinylidene or alkynyl derivatives. ${ }^{3 \mathrm{~b}, 15}$ At variance with this, fragments such as $\left\{\left[\mathrm{Cp} * \mathrm{Ru}\left({ }^{\mathrm{i}} \mathrm{Pr}_{2} \mathrm{PNHPy}\right)_{2}\right]^{+}\right\},{ }^{13 \mathrm{a}}\left\{\left[\mathrm{Cp} * \mathrm{Ru}(\mathrm{CO})\left(\mathrm{PMe}^{\mathrm{i}} \mathrm{Pr}_{2}\right)\right]^{+}\right\},{ }^{13 \mathrm{c}}$ $\left\{\left[\mathrm{CpRu}(\mathrm{CO})\left(\mathrm{P}^{\mathrm{i}} \mathrm{Pr}_{3}\right)\right]^{+}\right\},{ }^{11}$ and $\left\{\left[\left(\eta^{6} \text {-arene }\right) \mathrm{Ru}\left(\mathrm{PR}_{3}\right)\right]^{+}\right\}^{21}$ are more electron poor, and addition of nucleophiles to the allenylidene ligand occurs at the $\alpha$-carbon, furnishing vinyl-carbene or $\sigma$-allenyl complexes.

Although the vast majority of known allenylidene ruthenium complexes contain tertiary phosphines as coligands, there are a number of allenylidene derivatives bearing $\mathrm{N}$-heterocyclic carbene as ancillary ligands, instead of the classical phosphines. Thus, the complexes $\left[\left(\eta^{6}-p\right.\right.$-cymene $) \mathrm{Ru}=\mathrm{C}=\mathrm{C}=\mathrm{CPh}_{2}$ $(\mathrm{NHC})(\mathrm{Cl})][\mathrm{X}]\left(\mathrm{X}^{-}=\mathrm{PF}_{6}^{-}, \mathrm{TfO}^{-} ; \mathrm{NHC}=1,3-\mathrm{bis}(2,4,6-\right.$ trimethylphenyl)imidazol-2-ylidene, 1,3-bis(2,4,6-trimethylphenyl)dihydroimidazol-2-ylidene $)$ were obtained by reaction of $\left[\left(\eta^{6}-p\right.\right.$ cymene $\left.) \mathrm{RuCl}_{2}(\mathrm{NHC})\right]$ with $\mathrm{HC} \equiv \mathrm{CC}(\mathrm{OH}) \mathrm{Ph}_{2}$ in the presence of the corresponding halide scavenger ${ }^{22}$ or via replacement of the $\mathrm{PCy}_{3}$ ligand in $\left[\left(\eta^{6}-p\right.\right.$-cymene $\left.) \mathrm{Ru}=\mathrm{C}=\mathrm{C}=\mathrm{CPh}_{2}(\mathrm{Cl})\left(\mathrm{PCy}_{3}\right)\right]\left[\mathrm{PF}_{6}\right]$ by the $\mathrm{N}$-heterocyclic carbene. ${ }^{23} \mathrm{In}$ an analogous fashion, the complexes $\left[\mathrm{Ru}=\mathrm{C}=\mathrm{C}=\mathrm{CPh}_{2}(\mathrm{Cl})_{2}\left(\mathrm{PCy}_{3}\right)(\mathrm{NHC})\right]$ and $[\mathrm{Ru}=\mathrm{C}=\mathrm{C}=$ $\left.\mathrm{CPh}_{2}(\mathrm{Cl})_{2}(\mathrm{NHC})_{2}\right]$ were prepared by substitution of one or two $\mathrm{PCy}_{3}$ ligands, respectively, in $\left[\mathrm{Ru}=\mathrm{C}=\mathrm{C}=\mathrm{CPh}_{2}(\mathrm{Cl})_{2}\left(\mathrm{PCy}_{3}\right)_{2}\right]$ by $\mathrm{NHC}^{24}$ In particular, the complex $\left[\mathrm{Ru}=\mathrm{C}=\mathrm{C}=\mathrm{CPh}_{2}(\mathrm{Cl})_{2}\right.$ $\left.\left(\mathrm{PCy}_{3}\right)\left(\mathrm{IMesH}_{2}\right)\right] \quad\left(\mathrm{IMesH}_{2}=1,3\right.$-bis(2,4,6-trimethylphenyl)dihydroimidazol-2-ylidene) is a useful precursor for the preparation of further allenylidene derivatives such as $[\mathrm{Ru}=\mathrm{C}=\mathrm{C}=$ $\left.\mathrm{CPh}_{2}(\mathrm{Cl})_{2}(\mathrm{py})_{2}\left(\mathrm{IMesH}_{2}\right)\right]$ and the Schiff base complex ${ }^{25}$ shown in Chart 1.

\section{Chart 1}

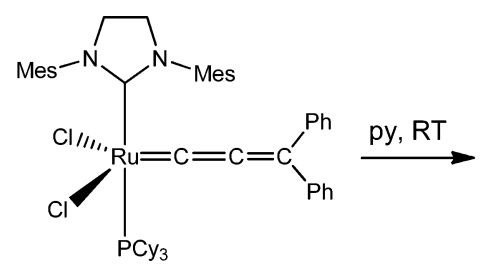<smiles>CN1CCN(C)C1[Ge](Cl)(Cl)C([Hg])=C=C(c1ccccc1)c1ccccc1</smiles><smiles>Cc1cc(Br)cc(C)c1N1C=C=C(c2ccccc2)c2cc([N+](=O)[O-])ccc2O[Te](Cl)(C=C=C(c2ccccc2)c2ccccc2)C1N1CCN(S(C)(=O)=O)C1</smiles>

These compounds were prepared as result of the exploration of new synthetic strategies in the development of chemically activated olefin metathesis catalysts (ROMP, RCM), some of them as alternatives to second-generation Grubbs catalysts. ${ }^{24,26}$

We became interested in the study of the reactivity of allenylidene ligands bound to a ruthenium center supported by $\mathrm{N}$-heterocyclic carbene ligands and in the general activation of propargyl alcohols by the Ru-NHC fragment. Following the recent works carried out in our group with $\mathrm{TpRu}$ complexes bearing potentially hemilabile picolyl-functionalized $\mathrm{N}$-heterocyclic carbene ligands, ${ }^{27,28}$ and given the scarcity of $\mathrm{TpRu}$ derivatives containing monodentate $\mathrm{NHC},{ }^{29}$ we focused our attention on $\mathrm{TpRu}$ complexes with the chelating bidentate ligand bis(3methylimidazol-2-ylidene)methane (L). ${ }^{30}$ Chelating bis-NHC ligands are expected to yield more stable metal complexes. Additionally, these ligands also provide interesting features that allow for the fine tuning of topological properties such as steric hindrance, bite angle, and fluxional behavior. ${ }^{31}$ In the present work we describe the synthesis of TpRu complexes bearing the chelating bidentate NHC ligand bis(3-methylimidazol-2ylidene)methane and their interaction with alkynols to yield alkoxy-vinylidene or allenylidene derivatives, depending on the nature of the substituents on the propargyl alcohol. The reactivity toward the addition of nucleophiles to the allenylidene ligand attached to the fragment $\left\{[\mathrm{TpRu}(\mathrm{L})]^{+}\right\}$has been studied in detail, and it is compared to that of related systems containing tertiary phosphines as ancillary ligands.

\section{RESULTS AND DISCUSSION}

Preparation of $[\mathrm{TpRuCl}(\mathrm{L})]$ (1) and Reactions with Chloride Scavengers. The complex $[\mathrm{TpRuCl}(\mathrm{COD})]$ reacts with the silver bis(carbene) $\mathbf{L} \cdot \mathrm{Ag}_{2} \mathrm{Cl}_{2}$ (obtained by reaction of $\left[\mathrm{LH}_{2}\right] \mathrm{Cl}_{2}$ with $\mathrm{Ag}_{2} \mathrm{O}$ in dichloroethane) in dichloroethane at $120^{\circ} \mathrm{C}$ for a period of $20 \mathrm{~h}$, furnishing the bis (carbene) derivative $[\mathrm{TpRuCl}(\mathrm{L})](\mathbf{1})$ (Chart 2), which was isolated as a dichloroethane solvate in the form of a dark green microcrystalline material.

A similar synthetic transmetalation procedure has been recently used for the preparation of a series of $\mathrm{TpRu}$ complexes bearing picolyl-functionalized N-heterocyclic carbene ligands. ${ }^{27}$ Compound $\mathbf{1}$ is fairly air and moisture stable in the solid state, and it was characterized by IR, NMR, and microanalysis. Its IR spectrum exhibits the characteristic $\nu(\mathrm{BH})$ band of the Tp ligand 


\section{Chart 2}

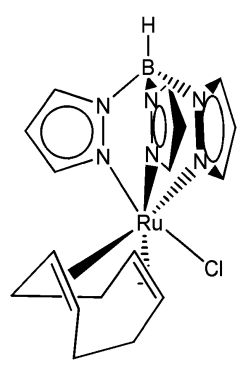

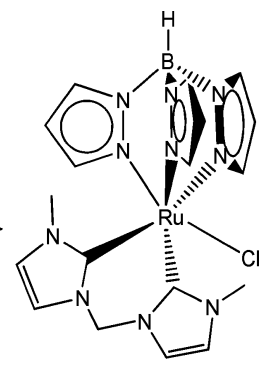

1

at $2453 \mathrm{~cm}^{-1}$. The ${ }^{1} \mathrm{H}$ NMR spectrum shows two characteristic $\mathrm{AB}$ doublet signals with a coupling constant of $11.5 \mathrm{~Hz}$ corresponding to the methylene bridge protons, which become diastereotopic upon bidentate coordination of the ligand to the $\mathrm{Ru}$ atom. Similar NMR features have been observed on $\mathrm{TpRu}$ and $\mathrm{Cp} * \mathrm{Ru}$ complexes bearing chelating $\kappa^{2} \mathrm{C}, \mathrm{N}$-pyridyl-NHC ligands. ${ }^{27,28,32}$ The protons of the Tp ligand give rise to six NMR proton resonance signals. The presence in the spectrum of two sets of three signals each, one of the sets having intensity double that of the other, is consistent with the presence of two equivalent pyrazole rings, plus another one that is nonequivalent. This pattern has been commonly observed for other TpRu complexes containing chelating bidentate phosphine ligands. ${ }^{16 e}$ The ${ }^{13} \mathrm{C}\left\{{ }^{1} \mathrm{H}\right\}$ NMR signal of the equivalent carbene carbon atoms of $\mathbf{1}$ is located as expected for $\mathrm{Ru}-\mathrm{NHC}$ compounds. ${ }^{27,28,30-33}$

Complex 1 reacts with $\mathrm{NaBAr}{ }_{4}^{\prime}\left(\mathrm{Ar}^{\prime}=3,5\right.$-bis(trifluoromethyl)phenyl) in fluorobenzene under $\mathrm{N}_{2}$, yielding a brown microcrystalline material which exhibits a strong band at $2153 \mathrm{~cm}^{-1}$ in its IR spectrum, attributable to $\nu(\mathrm{N} \equiv \mathrm{N})$ in a terminal dinitrogen ligand attached to $\mathrm{Ru}$. The ${ }^{1} \mathrm{H}$ NMR spectrum of this material in $\mathrm{CD}_{2} \mathrm{Cl}_{2}$ showed that it consists actually of a mixture of a major product (more than 60\%) accompanied by another minor product. Each of the products displays six NMR proton resonances for the Tp ligand and two $\mathrm{AB}$ doublet signals corresponding to the respective methylene bridge protons. On standing, the intensities of the signals for the minor product increase, at the expense of the intensities of the resonances for the major product. Recrystallization of the crude product from dichloromethane/petroleum ether afforded greenish gray crystals suitable for X-ray structure analysis. These crystals did not show any $\nu(\mathrm{N} \equiv \mathrm{N})$ band in their IR spectrum, and their ${ }^{1} \mathrm{H}$ NMR spectrum indicated the presence of a single product: namely, the minor product in the parent reaction. $\mathrm{X}$-ray structure analysis confirmed that this product is the bridging dinitrogen complex $\left[\{\mathrm{TpRu}(\mathrm{L})\}_{2}\left(\mu-\mathrm{N}_{2}\right)\right]\left[\mathrm{BAr}_{4}^{\prime}\right]_{2}$ (2). An ORTEP view of complex 2 is shown in Figure 1, together with the most relevant bond distances and angles.

The structure of the complex cation can be described as a centrosymmetric arrangement of $\left\{[\mathrm{TpRu}(\mathbf{L})]^{+}\right\}$moieties linked through a dinitrogen molecule. The crystallographic center of symmetry lies in the midpoint of the $\mathrm{N}-\mathrm{N}$ bond, making the two ruthenium sites equivalent. Each ruthenium adopts a distortedoctahedral geometry. The bis-carbene chelating bite angle $\mathrm{C}(10)-\mathrm{Ru}(1)-\mathrm{C}(15)$ of $79.4(2)^{\circ}$ is the lowest value reported for this ligand, which is usually in the range $83.2-87.8^{\circ} .30,33,34$ This is most likely due to the high steric demand imposed by the Tp ligand and the binuclear assembly of the two metal centers. The average dihedral angle between the plane defined by the atoms $\mathrm{C}(10)-\mathrm{Ru}(1)-\mathrm{C}(15)$ and the imidazole rings is $38.36^{\circ}$, much higher than the same angle observed for other pseudooctahedral complexes containing the same ligand $\mathbf{L}$ (range

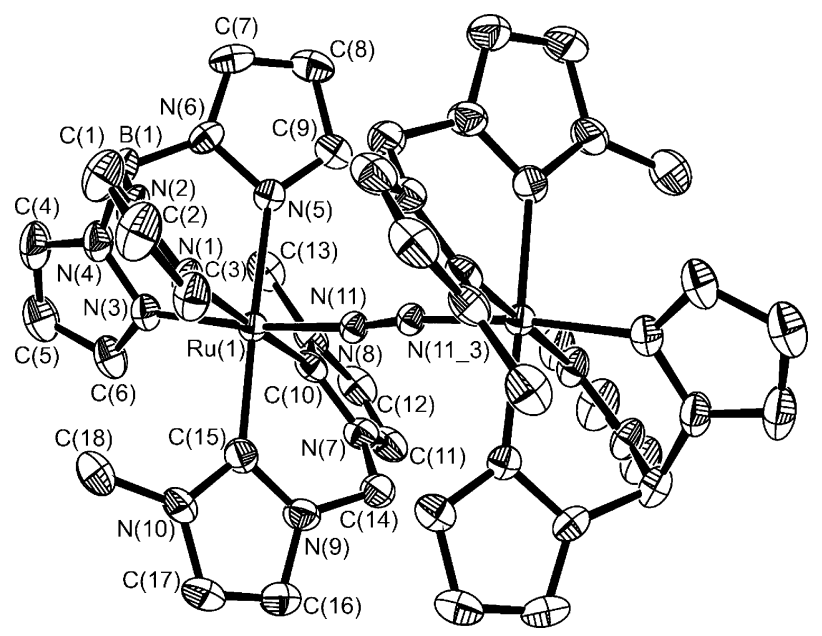

Figure 1. ORTEP drawing (50\% displacement ellipsoids, hydrogen atoms omitted) of $[\{\mathrm{TpRu}(\mathrm{bis}(3$-methylimidazol-2-ylidene)methane) $\left.\}_{2}\left(\mu-\mathrm{N}_{2}\right)\right]^{2+}$ in 2 . Selected bond lengths $(\AA)$ and angles (deg) with estimated standard deviations in parentheses: $\mathrm{Ru}(1)-\mathrm{C}(10)$ 1.963(5), $\mathrm{Ru}(1)-\mathrm{C}(15)$ 2.121(5), $\mathrm{Ru}(1)-\mathrm{N}(1)$ 2.061(4), $\mathrm{Ru}(1)-$ $\mathrm{N}(3) 2.072(4), \mathrm{Ru}(1)-\mathrm{N}(5)$ 2.203(4), $\mathrm{Ru}(1)-\mathrm{N}(11)$ 1.925(4), $\mathrm{N}(11)-\mathrm{N}(1133) \quad 1.117(7) ; \mathrm{Ru}(1)-\mathrm{N}(11)-\mathrm{N}(11$ 3) $171.6(5)$, $\mathrm{C}(10)-\mathrm{Ru}(1)-\mathrm{C}(15)$ 79.4(2), C(10)-Ru(1)-N(11) 91.10(17), $\mathrm{C}(15)-\mathrm{Ru}(1)-\mathrm{N}(11) \quad 89.62(18), \mathrm{N}(3)-\mathrm{Ru}(1)-\mathrm{N}(11)$ 172.64(17), $\mathrm{C}(15)-\mathrm{Ru}(1)-\mathrm{N}(5)$ 178.07(17), C(10)-Ru(1)-N(1) 178.74(19).

19.7-32.1 $\left.{ }^{\circ}\right) .^{30,33,34} \mathrm{The} \mathrm{Ru}-\mathrm{C}$ distances for the NHC ligand are 1.963(5) and 2.121(5) $\AA$, typical for $\mathrm{Ru}-\mathrm{C} \sigma$ bonds, but are indicative of a nonsymmetrical arrangement of the imidazolylidene rings. The dinitrogen ligand is linearly assembled to the two ruthenium atoms, as indicated by the value of the angle $\mathrm{Ru}-\mathrm{N} 11-\mathrm{N} 113$ of $171.6(5)^{\circ}$. The $\mathrm{Ru}-\mathrm{N}$ bond distance is 1.925(4) $\AA$, whereas the N11-N11_3 separation is 1.117(7) $\AA$. These values compare well with the bond distances recently reported for the dinitrogen-bridged $\mathrm{TpRu}$ complexes $[\{\mathrm{TpRu}-$ $\left(\kappa^{2} \mathrm{C}, N\right.$-picolyl- $\left.\left.\left.{ }^{\mathrm{Me}} \mathrm{I}\right)\right\}_{2}\left(\mu-\mathrm{N}_{2}\right)\right]\left[\mathrm{BAr}_{4}^{\prime}\right]_{2}$ (picolyl- ${ }^{\mathrm{Me}} \mathrm{I}=3$-methyl-1(2-picolyl)imidazol-2-ylidene; $\mathrm{Ru}-\mathrm{N}$ 1.883(6) $\AA, \mathrm{N}-\mathrm{N}$ $1.124(8) \AA)$ and $\left[\left\{\mathrm{TpRu}\left(\kappa^{2} \mathrm{C}, N \text {-picolyl- }{ }^{\mathrm{Ph}} \mathrm{I}\right)\right\}_{2}\left(\mu-\mathrm{N}_{2}\right)\right]\left[\mathrm{BAr}^{\prime}{ }_{4}\right]_{2}$ (picolyl- ${ }^{\mathrm{Ph}} \mathrm{I}=3$-phenyl-1-(2-picolyl)imidazol-2-ylidene; $\mathrm{Ru}-\mathrm{N}$ $1.941(4) \AA, N-\mathrm{N} 1.103(6) \AA),{ }^{27}$ as well as with the dimensions of the RuN $\equiv \mathrm{NRu}$ moiety found in other dinitrogen-bridged complexes of ruthenium. ${ }^{35,36}$ In all cases, the $\mathrm{N}-\mathrm{N}$ separation is only slightly longer than the bond length of $1.0977 \AA$ found for the free $\mathrm{N}_{2}$ molecule. ${ }^{37}$

We can interpret these results in terms of the formation of the labile terminal dinitrogen complex $\left[\mathrm{TpRu}\left(\mathrm{N}_{2}\right)(\mathrm{L})\right]\left[\mathrm{BAr}^{\prime}{ }_{4}\right]$ $\left(2^{\prime}\right)$ upon chloride abstraction from 1 under dinitrogen using $\mathrm{NaBAr}{ }_{4}^{\prime}$. The terminal dinitrogen complex $2^{\prime}$ loses $\mathrm{N}_{2}$ to yield the more stable dinuclear bridging dinitrogen complex 2 , as shown in Scheme 2.

We can attribute the observed IR band at $2153 \mathrm{~cm}^{-1}$ to $\nu(\mathrm{N} \equiv \mathrm{N})$ in $2^{\prime}$. As expected, this stretching band is inactive in the IR for the centrosymmetrical binuclear cation 2 , but it should be active in Raman. Thus, the Raman spectrum of $\mathbf{2}$ shows a strong band at $2106 \mathrm{~cm}^{-1}$ attributable to $\nu(\mathrm{N} \equiv \mathrm{N})$ in the bridging dinitrogen ligand. This band is shifted ca. $50 \mathrm{~cm}^{-1}$ to lower wavenumbers, indicative of a slight relaxation of the coordinated $\mathrm{N} \equiv \mathrm{N}$ in comparison with the terminal complex $2^{\prime}$. The values for IR and Raman $\nu(\mathrm{N} \equiv \mathrm{N})$ bands compare well with similar data in the literature for terminal ${ }^{35,38}$ and bridging ${ }^{27,35,36}$ dinitrogen complexes of ruthenium. It was not possible to obtain $2^{\prime}$ in pure form, as it always contained some amount of the bridging dinitrogen 
Scheme 2. Synthesis of the Dinitrogen Complexes 2 and 2'

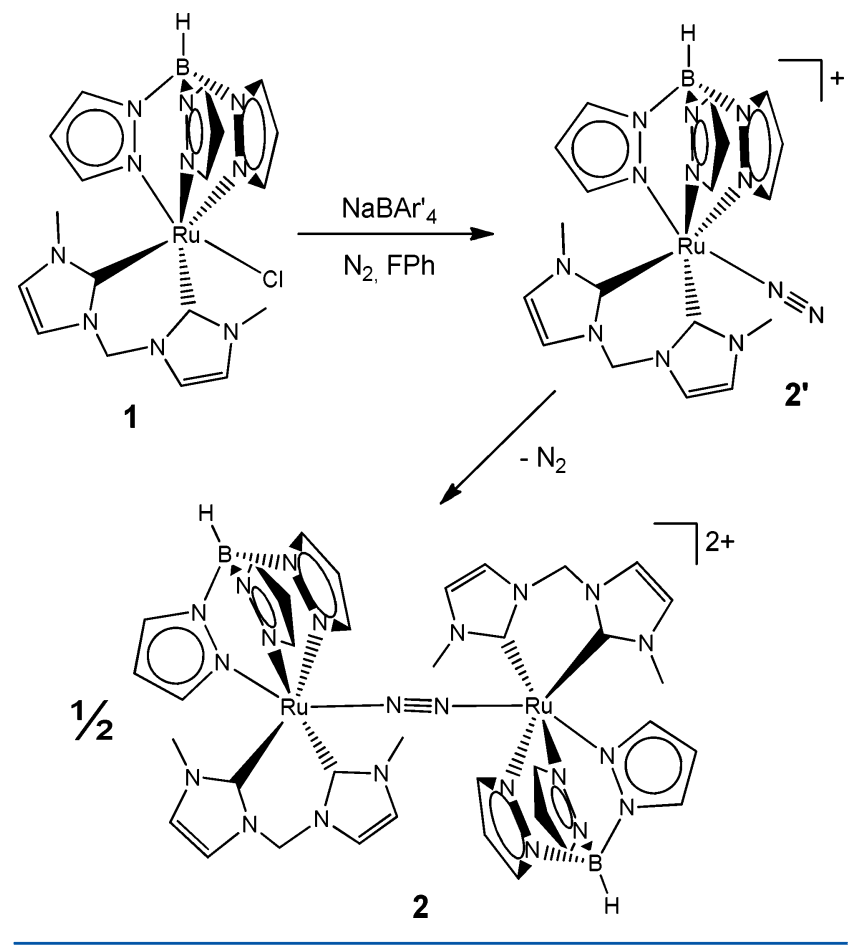

complex 2. However, it is possible to increase the amount of $\mathbf{2}$ by carrying out the halide abstraction under pressure of dinitrogen (3.6 atm). Under these conditions, ${ }^{1} \mathrm{H}$ NMR spectroscopy indicates that 2 is present in less than 15\%, although its concentration increases steadily with time.

Whereas the terminal dinitrogen ligand in $2^{\prime}$ seems quite labile, the bridging dinitrogen ligand in $\mathbf{2}$ is more strongly bound to the ruthenium atoms. Thus, 2 reacts with $\mathrm{CO}$ in dichloromethane, furnishing the carbonyl complex $[\mathrm{TpRu}(\mathrm{CO})(\mathrm{L})]$ $\left[\mathrm{BAr}_{4}{ }_{4}\right]$ (3). This compound exhibits one strong $\nu$ (CO) IR band at $1965 \mathrm{~cm}^{-1}$, a value which compares well with that observed for the complex $\left[\mathrm{TpRu}(\mathrm{CO})\left(\kappa^{2} \mathrm{C}, N\right.\right.$-picolyl- $\left.\left.{ }^{\mathrm{Me}} \mathrm{I}\right)\right]\left[\mathrm{BAr}_{4}^{\prime}\right]\left(1964 \mathrm{~cm}^{-1}\right) .^{27}$ Hence, a similar electron richness at the metal center for the fragments $\left\{\left[\mathrm{TpRu}\left(\kappa^{2} C, N \text {-picolyl- }{ }^{\mathrm{Me}} \mathrm{I}\right)\right]^{+}\right\}$and $\left\{[\mathrm{TpRu}(\mathbf{L})]^{+}\right\}$can be anticipated. When 2 is stirred under $\mathrm{CO}$ for more than $1 \mathrm{~h}$ at room temperature, the conversion into 3 is only $67 \%$, and longer reaction times are needed for achieving complete replacement of coordinated dinitrogen. We have studied by NMR spectroscopy the kinetics of substitution of coordinated dinitrogen in 2 by $\mathrm{CD}_{3} \mathrm{CN}$ to give $\left[\mathrm{TpRu}\left(\mathrm{CD}_{3} \mathrm{CN}\right)(\mathbf{L})\right]\left[\mathrm{BAr}^{\prime}{ }_{4}\right]$. We have measured the rate of disappearance of the dinitrogen complex by monitoring the decrease of the intensity of its ${ }^{1} \mathrm{H}$ NMR resonances for the 3,4-H atoms of the NHC rings as a function of time, using the software of the NMR spectrometer. We determined the values of pseudo-first-order rate constants $k_{\text {obs }}$ for the substitution reaction over a range of temperatures ranging from 40 to $75^{\circ} \mathrm{C}$. Listings of rate constants can be found in the Supporting Information. At $40{ }^{\circ} \mathrm{C}$, the substitution reaction is very slow, with a half-life of ca. $5 \mathrm{~h}$. At higher temperature, the reaction becomes much faster, with half-lives of 23 and $11 \mathrm{~min}$ at 60 and $70{ }^{\circ} \mathrm{C}$, respectively. Activation parameters were derived from the corresponding Eyring plot (Figure 2).

From the Eyring plot we have calculated the activation parameters $\Delta H^{\ddagger}=22 \pm 2 \mathrm{kcal} \mathrm{mol}^{-1}$ and $\Delta S^{\ddagger}=-9 \pm 6$ eu for the reaction of substitution of coordinated dinitrogen in 2 . From these values, it is possible to determine the value of $\Delta G^{\ddagger}{ }_{298}$,

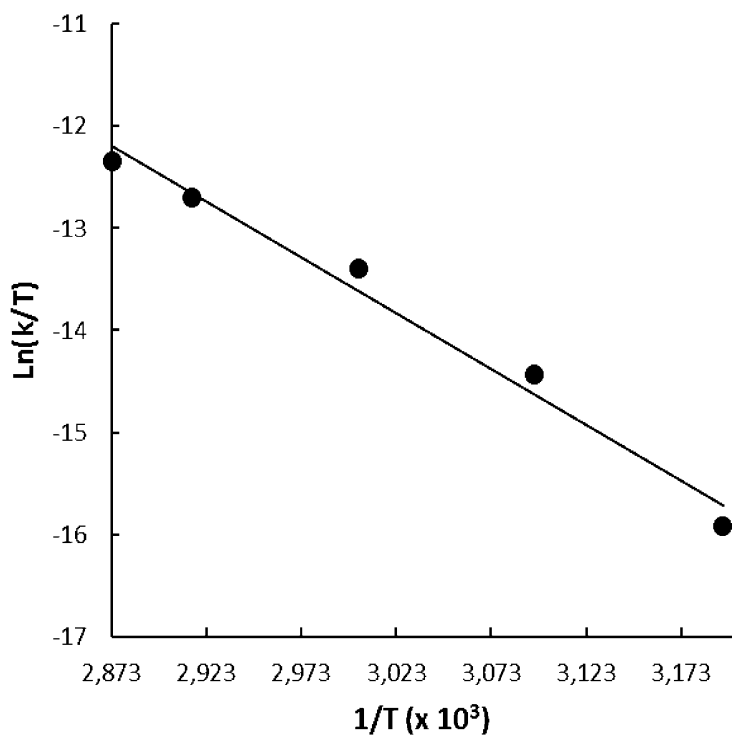

Figure 2. Eyring plot for the substitution of coordinated dinitrogen in 2 by $\mathrm{CD}_{3} \mathrm{CN}$.

which is $25 \pm 4 \mathrm{kcal} \mathrm{mol}^{-1}$. These values are consistent with the observation that the dinitrogen ligand is strongly bound to ruthenium in $\mathbf{2}$ and requires a significant activation energy for replacing it. $\Delta G^{\ddagger}{ }_{298}$ is higher than the calculated bond dissociation energies (BDE) of the dinitrogen ligand from ruthenium in terminal $\mathrm{Ru}\left(\mathrm{N}_{2}\right)$ complexes: i.e., $18.8 \mathrm{kcal} \mathrm{mol}^{-1}$ for $\left[\mathrm{Ru}\left(\mathrm{N}_{2}\right)(\mathrm{dmpe})_{2}\right]$ (dmpe = 1,2-bis(dimethylphosphino)ethane $)^{39}$ or $19.8 \mathrm{kcal} \mathrm{mol}^{-1}$ for the binding of $\mathrm{N}_{2}$ to the model fragment $\left[\mathrm{RuH}_{2}\left(\mathrm{PH}_{3}\right)_{2}\right]^{40}$ However, the determined value compares well with the BDE of $24.9 \mathrm{kcal} \mathrm{mol}^{-1}$ calculated for the bridging dinitrogen ligand in the molybdenum dinitrogen complex $\left[\left\{\mathrm{Mo}\left(\mathrm{N}_{2}\right)_{2}(\mathbf{P N P})\right\}_{2}\left(\mu-\mathrm{N}_{2}\right)\right] \quad(\mathbf{P N P}=2,6$-bis $($ di-tertbutylphosphinomethyl)pyridine). ${ }^{41}$ In this particular case, the high BDE contributes to the synergy between the two molybdenum moieties connected with the bridging dinitrogen ligand, in the context of its catalytic ability for the transformation of molecular dinitrogen into ammonia. ${ }^{41 a}$ The coordinatively unsaturated complex $\left[\mathrm{RuHCl}\left(\mathrm{N}_{2}\right)(\mathrm{IMes})_{2}\right]$ (IMes = 1,3-bis(2,4,6-trimethylphenyl)imidazol-2-ylidene) constitutes another recent example of unusually strong binding of dinitrogen to a ruthenium center. ${ }^{42}$ In this case, the terminal $\mathrm{N}_{2}$ ligand is strongly activated $\left(\nu(\mathrm{N} \equiv \mathrm{N}) 2041 \mathrm{~cm}^{-1}\right)$, with a calculated $\Delta G_{298}$ value for $\mathrm{N}_{2}$ loss of $17.8 \mathrm{kcal} \mathrm{mol}^{-1}$ which is higher than the value calculated for the loss of IMes $\left(14.6 \mathrm{kcal} \mathrm{mol}^{-1}\right)$. The strong binding is attributed to the simultaneous presence of a strongly $\sigma$ donating hydride ligand perpendicular to $\mathrm{N}_{2}$ and a $\pi$ donating $\mathrm{Cl}$ in a trans position, as well as to the donor properties of the IMes ligands. ${ }^{42}$

We have used in the past labile ruthenium dinitrogen complexes as suitable precursors for mechanistic studies on the interaction of half-sandwich phosphine complexes with propargyl alcohols and alkynes. ${ }^{16 b, c}$ However, the dinitrogen complex $\mathbf{2}$ is remarkably stable and relatively inert toward substitution of the coordinated dinitrogen ligand unless the reactions are carried out at elevated temperatures. Therefore, this material gives results unsuitable for the study of the intermediate species formed in the course of the interaction of propargyl alcohols by the fragment $\left\{[\mathrm{TpRu}(\mathbf{L})]^{+}\right\}$, as was our initial purpose. This prompted us to take a more direct approach and study the products derived directly from the reaction of 1 with propargyl alcohols in the presence of $\mathrm{NaBPh}_{4}$ as chloride scavenger. 
Reactivity of 1 toward Propargyl Alcohols. Complex 1 reacts with propargyl alcohols $\mathrm{HC} \equiv \mathrm{CC}(\mathrm{OH}) \mathrm{RR}^{\prime}\left(\mathrm{RR}^{\prime}=\mathrm{Me}_{2}\right.$, $\left.\left(\mathrm{CH}_{2}\right)_{5}, \mathrm{MePh}, \mathrm{HPh}\right)$ and $\mathrm{NaBPh}_{4}$ in $\mathrm{MeOH}$ at $50-60{ }^{\circ} \mathrm{C}$, yielding the corresponding $\gamma$-methoxyvinylidene complexes $\left[\mathrm{TpRu}=\mathrm{C}=\mathrm{CHC}(\mathrm{OMe}) \mathrm{RR}^{\prime}(\mathrm{L})\right]\left[\mathrm{BPh}_{4}\right]\left(\mathrm{RR}^{\prime}=\mathrm{Me}_{2}(\mathbf{4 a})\right.$, $\left.\left(\mathrm{CH}_{2}\right)_{5}(\mathbf{4 b}), \mathrm{MePh}(4 \mathbf{c}), \mathrm{HPh}(4 \mathbf{d})\right)$. At variance with this, the reaction of 1 with $\mathrm{HC} \equiv \mathrm{CCH}_{2} \mathrm{OH}$ under the same conditions did not yield the $\gamma$-methoxyvinylidene complex but the $\gamma$-hydroxyvinylidene $\left[\mathrm{TpRu}=\mathrm{C}=\mathrm{CHCH}_{2} \mathrm{OH}(\mathbf{L})\right]\left[\mathrm{BPh}_{4}\right]$ (5) (Scheme 3).

\section{Scheme 3. Reactions of 1 with Propargyl Alcohols $\mathrm{HC} \equiv \mathrm{CC}(\mathrm{OH}) \mathrm{RR}^{\prime}$ in $\mathrm{MeOH}$}

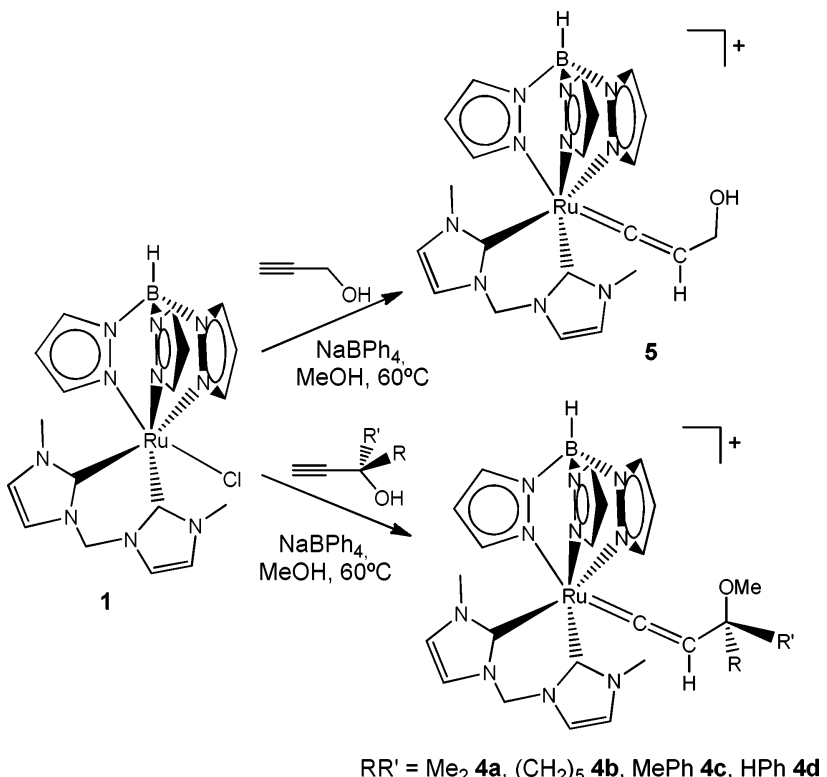

All of the new vinylidene complexes $4 \mathbf{a}-\mathbf{d}$ and $\mathbf{5}$ are characterized by the presence of a low-field resonance slightly above $350 \mathrm{ppm}$ in the ${ }^{13} \mathrm{C}\left\{{ }^{1} \mathrm{H}\right\}$ NMR spectra corresponding to the $\mathrm{C}_{\alpha}$ atom of the vinylidene ligand. The $\mathrm{C}_{\gamma}$ in complexes $\mathbf{4 c}, \mathbf{d}$ is chiral due to the different nature of the substituents attached. As a result, the two imidazolylcarbene rings of the chelating $\mathrm{NHC}$ ligand and the three pyrazole rings of the Tp become inequivalent. Hence, the ${ }^{1} \mathrm{H}$ and ${ }^{13} \mathrm{C}\left\{{ }^{1} \mathrm{H}\right\}$ NMR spectra of these complexes show two sets of resonances for the imidazolylcarbene groups and nine instead of six signals for the Tp proton and carbon atoms. The ${ }^{1} \mathrm{H}$ NMR spectra show two doublet signals for the methylene bridge protons in all cases.

The reaction of 1 with $\mathrm{HC} \equiv \mathrm{CC}(\mathrm{OH}) \mathrm{Ph}_{2}$ and $\mathrm{NaBPh}_{4}$ in $\mathrm{MeOH}$ at $60{ }^{\circ} \mathrm{C}$ led to the deep purple allenylidene derivative $\left[\mathrm{TpRu}=\mathrm{C}=\mathrm{C}=\mathrm{CPh}_{2}(\mathrm{~L})\right]\left[\mathrm{BPh}_{4}\right](\mathbf{6})$ instead of the corresponding $\gamma$-methoxyvinylidene complex. As has been observed in the case of half-sandwich phosphine complexes, ${ }^{16,18}$ this reaction is assumed to occur through the intermediacy of the $\gamma$-hydroxyvinylidene complex $\left[\mathrm{TpRu}=\mathrm{C}=\mathrm{CHC}(\mathrm{OH}) \mathrm{Ph}_{2}(\mathrm{~L})\right]$ $\left[\mathrm{BPh}_{4}\right]$ (not isolated in pure form), which undergoes spontaneous thermal dehydration, furnishing the final allenylidene product (Scheme 4).

The allenylidene complex 6 shows a strong $\nu(\mathrm{C}=\mathrm{C}=\mathrm{C})$ band in the IR spectrum at $1913 \mathrm{~cm}^{-1}$. The signals observed at $\delta$ 305.9, 223.7, and $145.8 \mathrm{ppm}$ in the ${ }^{13} \mathrm{C}\left\{{ }^{1} \mathrm{H}\right\}$ NMR spectrum are respectively characteristic for the $\mathrm{C}_{\alpha}, \mathrm{C}_{\beta}$, and $\mathrm{C}_{\gamma}$ atoms of the allenylidene ligand. These spectral properties compare well with
Scheme 4. Formation of the Allenylidene Complex 6

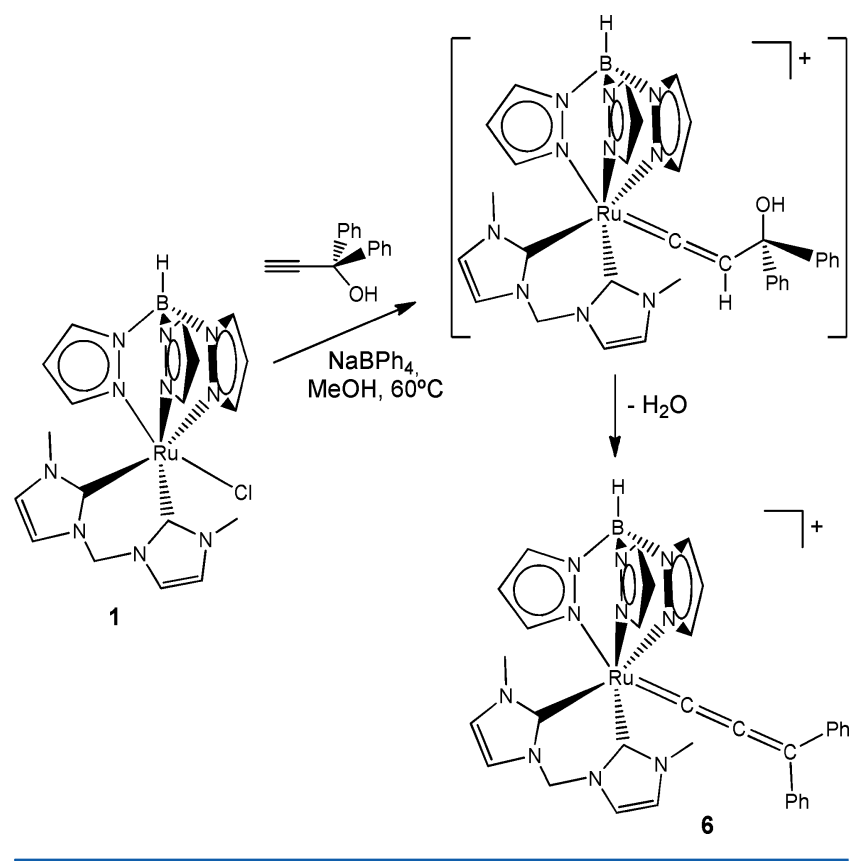

those found in other allenylidene complexes bearing tertiary phosphines as auxiliary ligands. ${ }^{13,16-19}$

The reactions of $\mathbf{1}$ and different propargyl alcohols $\mathrm{HC} \equiv$ $\mathrm{CC}(\mathrm{OH}) \mathrm{RR}^{\prime}$ in $\mathrm{MeOH}$ yielded different products depending on the nature of the $\mathrm{RR}^{\prime}$ substituents. The most general behavior was the propargylic substitution at the $\gamma$-carbon to give methoxyvinylidene complexes, but this does not occur with $\mathrm{HC} \equiv$ $\mathrm{CCH}_{2} \mathrm{OH}$ or $\mathrm{HC} \equiv \mathrm{CC}(\mathrm{OH}) \mathrm{Ph}_{2}$. We have interpreted these observations in terms of formation of the corresponding allenylidene complexes $\left[\mathrm{TpRu}=\mathrm{C}=\mathrm{C}=\mathrm{CRR}^{\prime}(\mathrm{L})\right]\left[\mathrm{BPh}_{4}\right]$ and subsequent attack of $\mathrm{MeOH}$ at the $\mathrm{C}_{\gamma}$ atom of the allenylidene ligand to yield the corresponding methoxyvinylidene complexes. It seems that in the case of the reaction with $\mathrm{HC} \equiv \mathrm{CC}(\mathrm{OH}) \mathrm{Ph}_{2}$ the allenylidene complex 6 is more stable and less reactive and does not add $\mathrm{MeOH}$ to the $\mathrm{C}_{\gamma}$. On the other hand, with $\mathrm{HC} \equiv \mathrm{CCH}_{2} \mathrm{OH}$ the reaction does not proceed beyond the stage of the hydroxyvinylidene complex 5 , given the fact that the propargylic substitution would require the formation of a primary allenylidene complex, i.e. $[\mathrm{TpRu}=\mathrm{C}=\mathrm{C}=$ $\left.\mathrm{CH}_{2}(\mathrm{~L})\right]\left[\mathrm{BPh}_{4}\right]$, prior to addition of $\mathrm{MeOH}$. Primary allenylidene complexes have so far proven to be elusive to isolation. Hence, all of the studied reactions involving propargyl alcohols with the exception of $\mathrm{HC} \equiv \mathrm{CCH}_{2} \mathrm{OH}$ seem to take place through the formation of reactive intermediate allenylidene complexes which add $\mathrm{MeOH}$ to the $\mathrm{C}_{\gamma}$ (Scheme 5).

These observations suggest that there is a preference for addition of nucleophiles to $\mathrm{C}_{\gamma}$ of the allenylidene ligand in these systems. In this sense, the reactivity of the TpRu allenylidene complexes bearing the bis-NHC ligand $\mathbf{L}$ seems similar to that displayed by electron-rich systems such as $\{[\mathrm{Cp} * \mathrm{Ru}-$ (dippe $\left.)]^{+}\right\}^{13 \mathrm{c}, 15 \mathrm{~b}, \mathrm{c}, 16 \mathrm{~b}, 20}$ and $\left\{\left[\mathrm{Cp} * \mathrm{Ru}\left(\mathrm{PEt}_{3}\right)_{2}\right]^{+}\right\}^{15 \mathrm{a}, 16 \mathrm{c}}$ bearing strongly electron releasing phosphines as auxiliary ligands. Complex 1 has shown so far to be inactive as a catalyst for the benchmark propargylic substitution reaction of $\mathrm{HC} \equiv \mathrm{CC}(\mathrm{OH})$ $\mathrm{MePh}$ with $\mathrm{MeOH}$ to give $\mathrm{HC} \equiv \mathrm{CC}(\mathrm{OMe}) \mathrm{MePh}$ (conditions: $5 \%$ catalyst load, $10 \% \mathrm{NaBF}_{4}$ or $\mathrm{NaBPh}_{4}$, 1,2-dichloroethane or $\mathrm{MeOH}, 60{ }^{\circ} \mathrm{C}$ ).

The lack of reactivity of the allenylidene complex 6 toward alcohols led us to carry out a more detailed study of its reactivity 
Scheme 5. Formation of Methoxyvinylidene Complexes through Intermediate Allenylidene Species

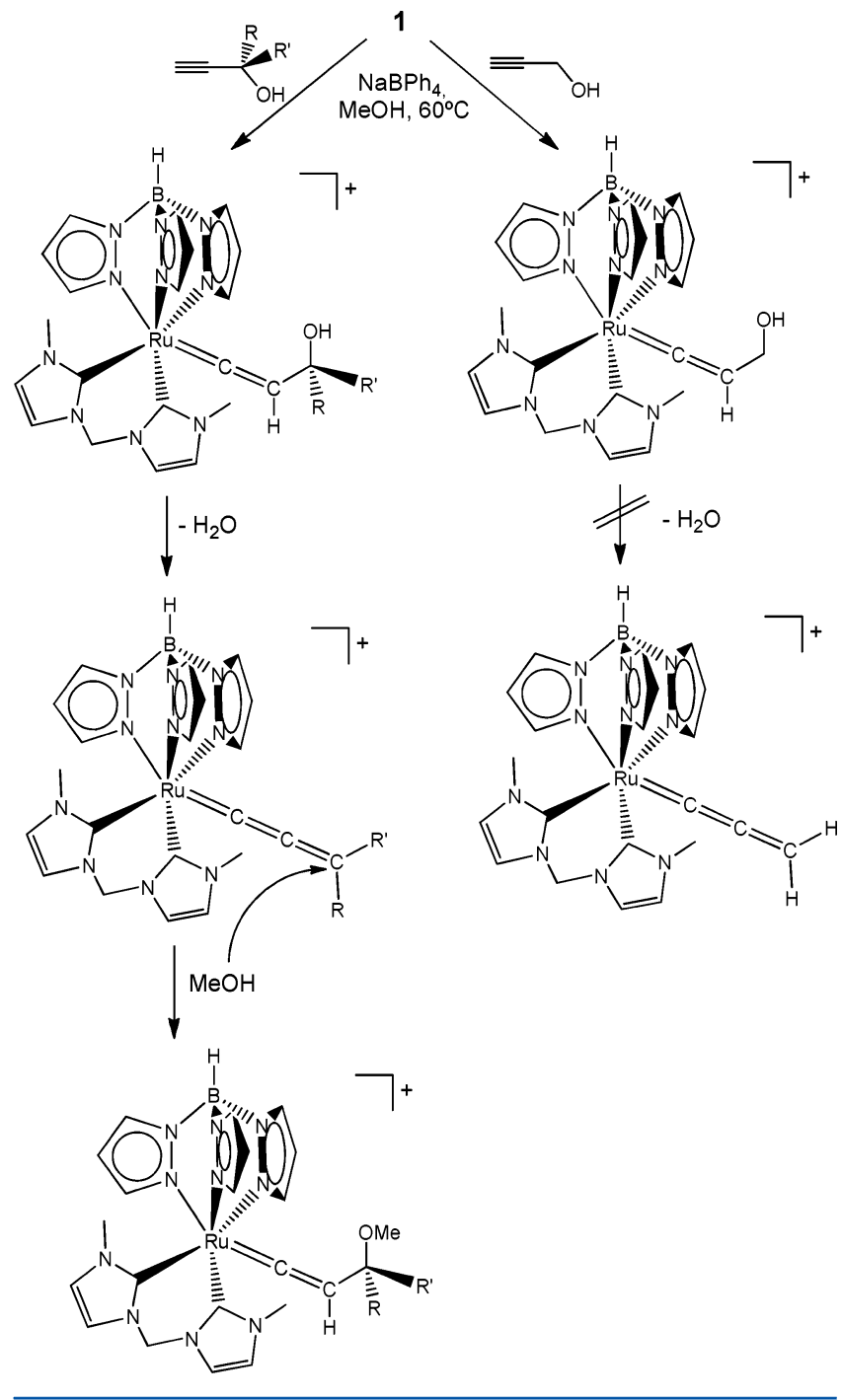

toward a variety of nucleophiles. The allenylidene complex 6 reacts with pyrazole in 1,2-dichloroethane at $80^{\circ} \mathrm{C}$ over a period of $18 \mathrm{~h}$, yielding a deep green solution, from which dark green crystals were isolated. If we assume a behavior formally analogous to the reactivity observed toward the addition of $\mathrm{MeOH}$ in the other cases, the addition of pyrazole to the $\mathrm{C}_{\gamma}$ of the allenylidene would lead to a vinylidene derivative: i.e., $[\mathrm{TpRu}=\mathrm{C}=\mathrm{CHC}$ $\left.\left(\mathrm{C}_{3} \mathrm{H}_{3} \mathrm{~N}_{2}\right) \mathrm{Ph}_{2}(\mathrm{~L})\right]\left[\mathrm{BPh}_{4}\right]$. However, the ${ }^{13} \mathrm{C}\left\{{ }^{1} \mathrm{H}\right\}$ NMR spectrum of the green crystals did not show the characteristic lowfield resonance near $350 \mathrm{ppm}$ expected for the $\mathrm{C}_{\alpha}$ of a vinylidene ligand. Instead, one signal at $283.3 \mathrm{ppm}$ was observed, more consistent with a carbenic carbon atom attached to ruthenium. The ${ }^{1} \mathrm{H}$ NMR spectrum of the green crystals was complex and temperature-dependent. At room temperature the spectrum showed one broad resonance at $2.59 \mathrm{ppm}$ for the protons of the methyl groups of the NHC ligand $\mathbf{L}$. When the temperature was lowered to $-40{ }^{\circ} \mathrm{C}$, decoalescence of this resonance to two separate singlet signals was observed, indicative of the nonequivalence of the methyl groups in the imidazolylidene rings. Consistent with this, the ${ }^{13} \mathrm{C}\left\{{ }^{1} \mathrm{H}\right\}$ NMR spectrum at this temperature showed two methyl carbon resonances and two signals for the rutheniumbound carbon atoms of the chelating NHC ligand. These spectral data were interpreted in terms of the addition of pyrazole to the $\mathrm{C}_{\alpha}$ of the allenylidene ligand in $\mathbf{6}$, resulting in the formation of the vinylcarbene complex $\left[\mathrm{TpRu}=\mathrm{C}\left(\mathrm{C}_{3} \mathrm{H}_{3} \mathrm{~N}_{2}\right) \mathrm{CH}=\mathrm{CPh}_{2}(\mathbf{L})\right]$ $\left[\mathrm{BPh}_{4}\right]$ (7). Single crystals of the solvate $7 \cdot \mathrm{CH}_{2} \mathrm{Cl}_{2}$, suitable for $\mathrm{X}$-ray analysis, were obtained by recrystallization from dichloromethane/petroleum ether. An ORTEP view of the cationic complex in 7 is shown in Figure 3, together with the most relevant bond distances and angles.

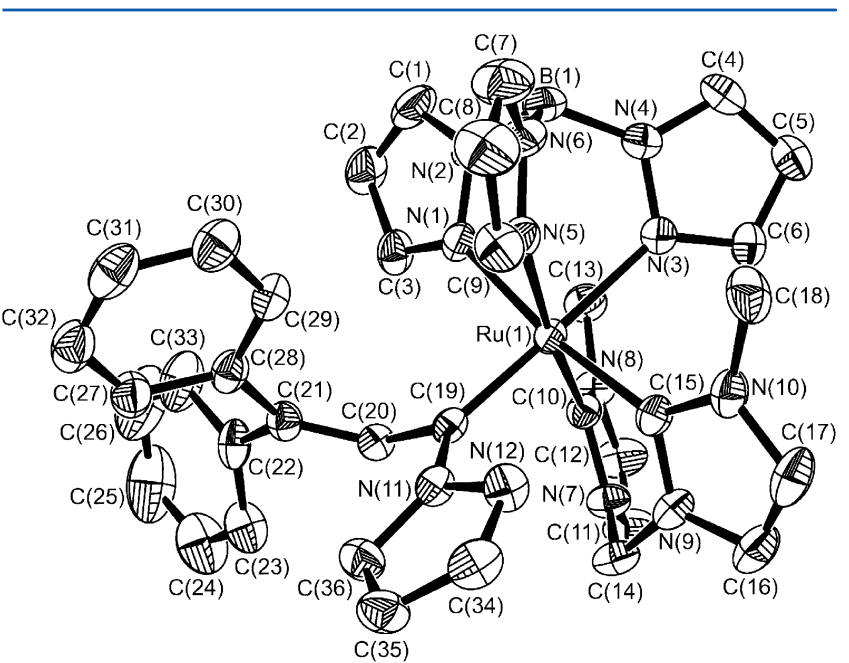

Figure 3. ORTEP drawing ( $30 \%$ displacement ellipsoids, hydrogen atoms omitted $)$ of $\left[\mathrm{TpRu}=\mathrm{C}\left(\mathrm{C}_{3} \mathrm{H}_{3} \mathrm{~N}_{2}\right) \mathrm{CH}=\mathrm{CPh}_{2}(\mathrm{~L})\right]^{+}$in 7 . Selected bond lengths $(\AA)$ and angles (deg) with estimated standard deviations in parentheses: $\mathrm{Ru}(1)-\mathrm{C}(10)$ 2.044(5), $\mathrm{Ru}(1)-\mathrm{C}(15)$ 2.010(5), $\mathrm{Ru}(1)-$ $\mathrm{N}(1) 2.188(4), \mathrm{Ru}(1)-\mathrm{N}(3) 2.169(4), \mathrm{Ru}(1)-\mathrm{N}(5) 2.168(4)$, $\mathrm{Ru}(1)-\mathrm{C}(19)$ 1.921(5), C(19)-N(11) 1.392(6), C(19)-C(20) 1.482(6), C(20)-C(21) 1.341(7); C(10)-Ru(1)-C(15) 85.2(2), $\mathrm{Ru}(1)-\mathrm{C}(19)-\mathrm{N}(11) \quad 129.6(3), \mathrm{C}(20)-\mathrm{C}(19)-\mathrm{N}(11)$ 111.1(4), $\mathrm{C}(19)-\mathrm{C}(20)-\mathrm{C}(21)$ 130.1(5), C(28)-C(21) $-\mathrm{C}(22)$ 117.5(4), $\mathrm{N}(3)-\mathrm{Ru}(1)-\mathrm{C}(19) 178.80(16), \mathrm{C}(15)-\mathrm{Ru}(1)-\mathrm{N}(1)$ 95.06(18), $\mathrm{C}(10)-\mathrm{Ru}(1)-\mathrm{N}(5)$ 174.39(18).

The structure of 7 is distorted octahedral. The bis-carbene chelating bite angle $\mathrm{C}(10)-\mathrm{Ru}(1)-\mathrm{C}(15)$ of $85.2(2)^{\circ}$ is within the expected range $83.2-87.8^{\circ 30,33,34}$ and is not unusually small, as it occurs in the case of the binuclear complex 2 . The average dihedral angle between the plane defined by the atoms $\mathrm{C}(10)-$ $\mathrm{Ru}(1)-\mathrm{C}(15)$ and the imidazole rings is $37.50^{\circ}$, still above the average values for the same angle in other complexes containing the same ligand $\mathbf{L}$ (range $\left.19.7-32.1^{\circ}\right) .^{30,33,34}$ The $\mathrm{Ru}-\mathrm{C}$ distances for the NHC ligand of 2.044(5) and 2.010(5) $\AA$ are both of the same order and are consistent with $\mathrm{Ru}-\mathrm{C}$ separations expected for $\sigma$ bonds. The $\mathrm{Ru}(1)-\mathrm{C}(19)$ bond length of 1.921 (5) $\AA$ is longer than that in the diphenylvinylcarbene $[\mathrm{Ru}=$ $\left.\mathrm{CHCH}=\mathrm{CPh}_{2}(\mathrm{Cl})_{2}\left({ }^{t} \mathrm{Bu}_{2} \mathrm{PCH}_{2} \mathrm{P}^{\mathrm{t}} \mathrm{Bu}_{2}\right)\right](1.838(6) \AA)^{43}$ but is essentially identical with the values of 1.916(7) and 1.913(3) $\AA$ measured for the $\mathrm{Ru}-\mathrm{C}$ bond distances in the carbene complexes $\left[\mathrm{Cp} * \mathrm{Ru}=\mathrm{CHPh}\left({ }^{\mathrm{i}} \mathrm{Pr}_{2} \mathrm{PNHPy}\right)\right]\left[\mathrm{PF}_{6}\right]^{44}$ and $[\mathrm{Cp} * \mathrm{Ru}=$ $\left.\mathrm{CHCH}=\mathrm{CPh}_{2}\left({ }^{\mathrm{i}} \mathrm{Pr}_{2} \mathrm{PNHPy}\right)\right]\left[\mathrm{PF}_{6}\right],{ }^{13 a}$ respectively. The distance $\mathrm{C}(19)-\mathrm{N}(11)$ of $1.392(6) \AA$ is longer than the $\mathrm{C}_{\alpha}-\mathrm{N}$ separations in complexes such as $[\mathrm{Cp} * \mathrm{Ru}\{\mathrm{C}(\mathrm{NHCy}) \mathrm{CH}=$ $\left.\left.\mathrm{CPh}_{2}\right\}\left({ }^{\mathrm{i}} \mathrm{Pr}_{2} \mathrm{PNHPy}\right)\right]\left[\mathrm{PF}_{6}\right]^{13 \mathrm{a}}(1.317(4) \AA)$ and $[\mathrm{CpRu}\{\mathrm{C}$ $\left.\left.\left(\mathrm{NEt}_{2}\right) \mathrm{CH}=\mathrm{CPh}_{2}\right\}(\mathrm{CO})\left(\mathrm{P}^{\mathrm{i}} \mathrm{Pr}_{3}\right)\right]\left[\mathrm{BF}_{4}\right](1.306(7) \AA)^{11 \mathrm{~b}}$ and is only slightly shorter than the standard value for a nitrogenaromatic carbon single bond (1.42 $\mathrm{A})$. The ligand resulting from the addition of pyrazole to the allenylidene fragment can be considered as a diphenyl(pyrazolyl)carbene or alternatively as an azoniabutadienyl derivative, depending on the relative contribution of the resonance structures shown in Chart 3. 


\section{Chart 3}

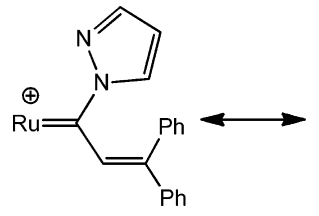

A

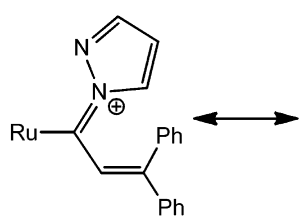

B

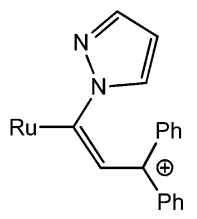

C
The X-ray crystal structures of many complexes derived from the addition of amines to the $\mathrm{C}_{\alpha}$ of an allenylidene ligand suggest that these compounds are better described as azoniabutadienyl derivatives (structure B), given the observed sequence of bond lengths across the ligands. ${ }^{11 b, 13 a, c}$ However, this is not the case for 7, which can be better considered a diphenyl(pyrazolyl)carbene derivative (structure A), as inferred from the $\mathrm{Ru}(1)-$ $\mathrm{C}(19)$ and $\mathrm{C}(19)-\mathrm{N}(11)$ bond distances. The pyrazolyl ring and the carbon atoms $\mathrm{C}(19)$ and $\mathrm{C}(20)$ in 7 fall in a plane which forms an angle of $78^{\circ}$ with the plane defined by the atoms $C(19)$, $\mathrm{Ru}(1)$, and $\mathrm{B}(1)$. With this arrangement, the two imidazolylidene rings of the $\mathrm{L}$ ligand and the three pyrazole groups of the $\mathrm{Tp}$ ligand become inequivalent. Thus, the dependence of the NMR spectra on the temperature is most likely caused by the existence of restricted rotation around $\mathrm{Ru}(1)-\mathrm{C}(19)$ due to its doublebond character, with a rather high energy barrier.

It is demonstrated that the allenylidene complex $\mathbf{6}$ adds pyrazole at the $\mathrm{C}_{\alpha}$ atom rather than to the $\mathrm{C}_{\gamma}$. Other molecules are also capable of attacking the allenylidene ligand in $\mathbf{6}$ at the $\mathrm{C}_{\alpha}$ to yield the corresponding diphenylvinylcarbene species. Thus, 6 reacts with piperidine in dichloromethane, furnishing $[\mathrm{TpRu}=$ $\left.\mathrm{C}\left(\mathrm{N}\left(\mathrm{CH}_{2}\right)_{4} \mathrm{CH}_{2}\right) \mathrm{CH}=\mathrm{CPh}_{2}(\mathrm{~L})\right]\left[\mathrm{BPh}_{4}\right](8)$ in the form of redorange crystals. The NMR spectra of this compound are not temperature dependent, at variance with the case for 7 . Both ${ }^{1} \mathrm{H}$ and ${ }^{13} \mathrm{C}\left\{{ }^{1} \mathrm{H}\right\}$ NMR spectra indicate the nonequivalence of the imidazolylidene rings in $\mathbf{L}$ and of the three pyrazole rings in the Tp ligand. Thus, two separate resonances are observed for the ruthenium-bound carbon atoms of the NHC ligand $\mathbf{L}$. The carbon atom of the diphenyl(piperidyl)carbene ligand directly attached to ruthenium appears at $259.3 \mathrm{ppm}$. The reactions of the allenylidene complex 6 with the $S$ donors 2-pyridinethiol and 1,3-benzenedithiol led to the corresponding products of addition to the $\mathrm{C}_{\alpha}$ atom, namely $\left[\mathrm{TpRu}=\mathrm{C}\left(\mathrm{SC}_{5} \mathrm{H}_{4} \mathrm{~N}\right) \mathrm{CH}=\mathrm{CPh}_{2}(\mathbf{L})\right]$ $\left[\mathrm{BPh}_{4}\right](\mathbf{9})$ and $\left[\mathrm{TpRu}=\mathrm{C}\left(\mathrm{SC}_{5} \mathrm{H}_{4} \mathrm{SH}\right) \mathrm{CH}=\mathrm{CPh}_{2}(\mathbf{L})\right]\left[\mathrm{BPh}_{4}\right]$ (10). As for 8, these compounds also have inequivalent $\mathrm{Tp}$ pyrazole groups and imidazolylidene rings, and their NMR spectra are not temperature dependent. This observation suggests that the barriers to rotation around the $\mathrm{Ru}=\mathrm{C}$ bonds are much higher for these compounds in comparison to that for 7, presumably as a result of the higher steric demand of the fragments attached to the $\mathrm{C}_{\alpha}$ atom. The analogies in the NMR spectra of compounds 7-10 suggest similar structures for all of them, which are summarized in Scheme 6.

The observed reactivity of the allenylidene complex 6 appears dominated by the addition of nucleophiles to the $\mathrm{C}_{\alpha}$ atom of the carbon chain. This pattern of reactivity is more characteristic of systems containing electron-poor metal centers such as $\left\{\left[\mathrm{Cp} * \mathrm{Ru}\left({ }^{\mathrm{i}} \mathrm{Pr}_{2} \mathrm{PNHPy}\right)_{2}\right]^{+}\right\},{ }^{13 \mathrm{a}}\left\{\left[\mathrm{Cp} * \mathrm{Ru}(\mathrm{CO})\left(\mathrm{PMe}^{\mathrm{i}} \mathrm{Pr}_{2}\right)\right]^{+}\right\},{ }^{13 \mathrm{c}}$ and $\left\{\left[\mathrm{CpRu}(\mathrm{CO})\left(\mathrm{P}^{\mathrm{i}} \mathrm{Pr}_{3}\right)\right]^{+}\right\}$. ${ }^{11}$ This contradicts previous observations (vide supra), which indicated that the reactivity of 1 toward propargyl alcohols in $\mathrm{MeOH}$ was more similar to that of systems containing electron-rich metal centers. Thus, it seems that the actual reactivity pattern of a metal complex toward substituted propargyl alcohols depends strongly on the nature of substituents present at the alcohol, and not only on the steric and electronic properties of the ancillary ligands attached to the metal. Furthermore, complex 6 reacts with $\mathrm{KOBu}^{\mathrm{t}}$ in acetone, furnishing the neutral $\sigma$-alkynyl derivative $[\mathrm{TpRuC} \equiv \mathrm{CC}$ $\left.\left(\mathrm{CH}_{2} \mathrm{COCH}_{3}\right) \mathrm{Ph}_{2}(\mathrm{~L})\right](\mathbf{1 1})$, resulting from the addition of the potassium enolate of acetone generated in situ to the $\mathrm{C}_{\gamma}$ of the allenylidene ligand, and not to the $\mathrm{C}_{\alpha}$ atom (Scheme 7).

Addition to the $\mathrm{C}_{\alpha}$ atom would have led to a $\sigma$-allenyl complex. Species of this kind have been observed in the course of the addition of phosphines to the $\mathrm{C}_{\alpha}$ of allenylidene complexes. ${ }^{13 c, 45}$ Although complex 11 has not been characterized by X-ray crystallography, its IR and NMR features leave no doubt about its structure. A strong $\nu(\mathrm{C} \equiv \mathrm{C})$ band is observed at $2061 \mathrm{~cm}^{-1}$ in its IR spectrum, which is typical for alkynyl complexes such as $\left[\mathrm{Cp} * \mathrm{RuC} \equiv \mathrm{CC}\left(\mathrm{CH}_{2} \mathrm{COCH}_{3}\right) \mathrm{RPh}(\right.$ dippe $\left.)\right](\mathrm{R}=\mathrm{Ph}, \mathrm{H}){ }^{15 \mathrm{c}}$ In the case of formation of a $\sigma$-allenyl complex, the IR band for $\nu(\mathrm{C}=\mathrm{C}=\mathrm{C})$ would have been observed below $1900 \mathrm{~cm}^{-1}$. $13 \mathrm{c}, 45$ These results indicate that, depending on the nature of the nucleophile, the addition to the allenylidene ligand in 6 may occur alternatively at $\mathrm{C}_{\alpha}(\mathrm{N}$ and $\mathrm{S}$ donors $)$ or at $\mathrm{C}_{\gamma}$ ( $\mathrm{C}$ donors $)$.

\section{CONCLUSION}

The TpRu moiety supported by the bidentate NHC ligand bis(3methylimidazol-2-ylidene)methane $(\mathbf{L})$ is capable of binding dinitrogen, furnishing the labile end-on dinitrogen complex $\mathbf{2}^{\prime}$, which is readily transformed into the remarkably stable bridging dinitrogen complex 2. Propargyl alcohols also bind to the $[\mathrm{TpRu}(\mathbf{L})]^{+}$fragment, generating reactive intermediate allenylidene complexes which undergo addition of $\mathrm{MeOH}$ at the $\mathrm{C}_{\gamma}$ atom to give methoxyvinylidene derivatives. In spite of this chemical behavior, complex $\mathbf{1}$ is not active for the catalytic propargylic substitution reaction of $\mathrm{HC} \equiv \mathrm{CC}(\mathrm{OH}) \mathrm{MePh}$ with $\mathrm{MeOH}$ to give $\mathrm{HC} \equiv \mathrm{CC}(\mathrm{OMe}) \mathrm{MePh}$. It was possible to isolate the allenylidene complex 6 , which has shown a rich reactivity toward nucleophiles and protons. In this case, depending upon the nature of the nucleophile, addition may occur either at the $\mathrm{C}_{\alpha}$ atom (neutral $\mathrm{N}$ - and $\mathrm{S}$-donor molecules) or at the $\mathrm{C}_{\gamma}$ (anionic $\mathrm{C}$-donor nucleophile). The result is the respective formation of diphenylvinylcarbene complexes (compounds 7-10) or the neutral $\sigma$-alkynyl derivative 12 . The X-ray crystal structure of 7 . $\mathrm{CH}_{2} \mathrm{Cl}_{2}$ suggests that it can be can be considered a genuine diphenyl(pyrazolyl)carbene derivative. This contrasts sharply with the case of related species derived from the addition of nucleophiles to the $\mathrm{C}_{\alpha}$ atom of allenylidene complexes containing tertiary phosphines as auxiliary ligands instead of NHC ligands, which are better described as azoniabutadienyl derivatives. Taken together, these findings indicate that the reactivity patterns of the fragment $[\mathrm{TpRu}(\mathrm{L})]^{+}$toward propargyl alcohols can be considered as intermediate between those characteristic of electron-rich and electron-poor $\mathrm{Ru}$ centers as defined in the literature. Hence, the bidentate NHC ligand does not condition the selectivity of nucleophilic additions, which may take place alternatively at the $\mathrm{C}_{\alpha}$ or $\mathrm{C}_{\beta}$ atoms depending on the $\mathrm{R}$ substituents present on the propargyl alcohol and on the nature of the incoming nucleophiles.

\section{EXPERIMENTAL SECTION}

All synthetic operations were performed under a dry dinitrogen or argon atmosphere following conventional Schlenk techniques. Tetrahydrofuran, diethyl ether, and petroleum ether (boiling point range $40-60{ }^{\circ} \mathrm{C}$ ) were obtained oxygen- and water-free from a solvent purification apparatus. Acetone, dichloromethane, and toluene were of anhydrous 
Scheme 6. . Reactions of the Allenylidene Complex 6 with N- and S-Donor Molecules

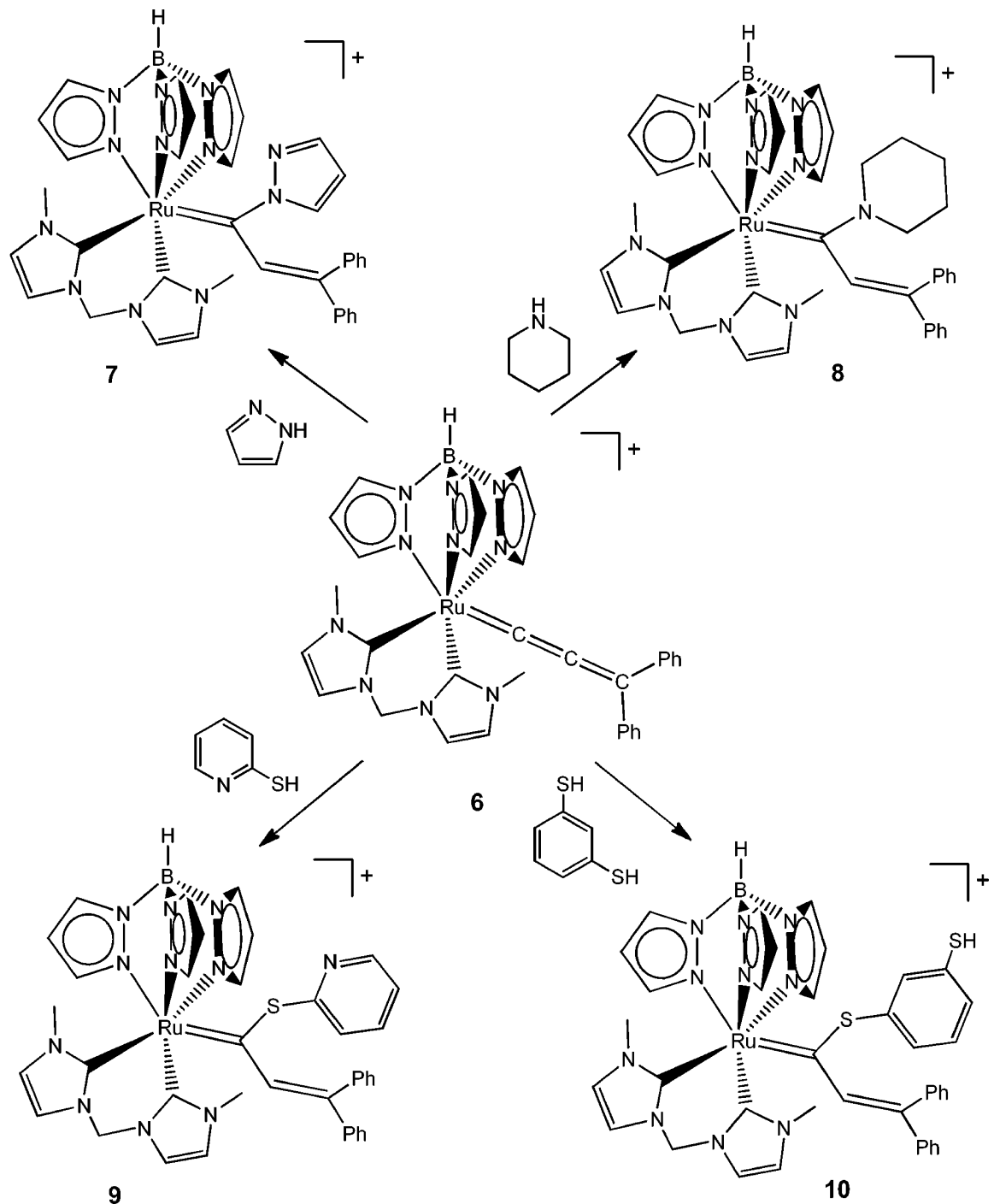

9

10

quality and were used as received. All solvents were deoxygenated immediately before use. $[\mathrm{TpRuCl}(\mathrm{COD})]$ was prepared according to a recently reported procedure. ${ }^{46}$ The imidazolium salt bis $(3-$ methylimidazolium)methane dichloride $\left(\left[\mathrm{LH}_{2}\right] \mathrm{Cl}_{2}\right)$ was prepared following suitable adaptations of published procedures. ${ }^{30}$ IR spectra were taken in Nujol mulls on a FTIR spectrophotometer. Raman spectra were recorded at the Instituto de Ciencia de Materiales-CSIC on a dispersive Raman microscope equipped with a $\mathrm{He}-\mathrm{Ne}$ laser $(\lambda 532.14 \mathrm{~nm})$ using a working power of $0.2 \mathrm{~mW}$ in order to avoid overheating and alteration of the sample. NMR spectra were taken on a spectrometer operating at $500 \mathrm{MHz}\left({ }^{1} \mathrm{H}\right.$ frequency). Chemical shifts are given in ppm from $\mathrm{SiMe}_{4}\left({ }^{1} \mathrm{H}\right.$ and $\left.{ }^{13} \mathrm{C}\left\{{ }^{1} \mathrm{H}\right\}\right) .{ }^{1} \mathrm{H}$ and ${ }^{13} \mathrm{C}\left\{{ }^{1} \mathrm{H}\right\}$ NMR spectroscopic signal assignments were confirmed by ${ }^{1} \mathrm{H}$-gCOSY, gHSQCAD $\left({ }^{1} \mathrm{H}-{ }^{13} \mathrm{C}\right)$, and gHMBCAD $\left({ }^{1} \mathrm{H}-{ }^{13} \mathrm{C}\right)$ experiments. Microanalyses were performed at the Servicio Central de Ciencia y Tecnología, Universidad de Cádiz.

$[\mathrm{TpRuCl}(\mathrm{L})]$ (1). A Fisher-Porter vessel was charged with a mixture of bis(3-methylimidazolium)methane dichloride $(0.42 \mathrm{~g}, 2 \mathrm{mmol})$ and $\mathrm{Ag}_{2} \mathrm{O}(0.51 \mathrm{~g}, 2.2 \mathrm{mmol})$. It was protected from the light by wrapping with aluminum foil. Then, 1,2-dichloroethane $(30 \mathrm{~mL})$ was added, and the mixture was stirred at room temperature for $18 \mathrm{~h}$. After this time, a solution of $[\mathrm{TpRuCl}(\mathrm{COD})](0.92 \mathrm{~g}, 2 \mathrm{mmol})$ in 1,2-dichloroethane $(35 \mathrm{~mL})$ was added. The resulting mixture was stirred for a further $18 \mathrm{~h}$ at $130^{\circ} \mathrm{C}$. A dark green suspension was obtained. It was filtered through Celite, and the Celite was washed with two portions of dichloromethane. The solvent of the filtered solution was removed in vacuo. The resulting
Scheme 7. Reactivity of 6 toward Acetone Enolate

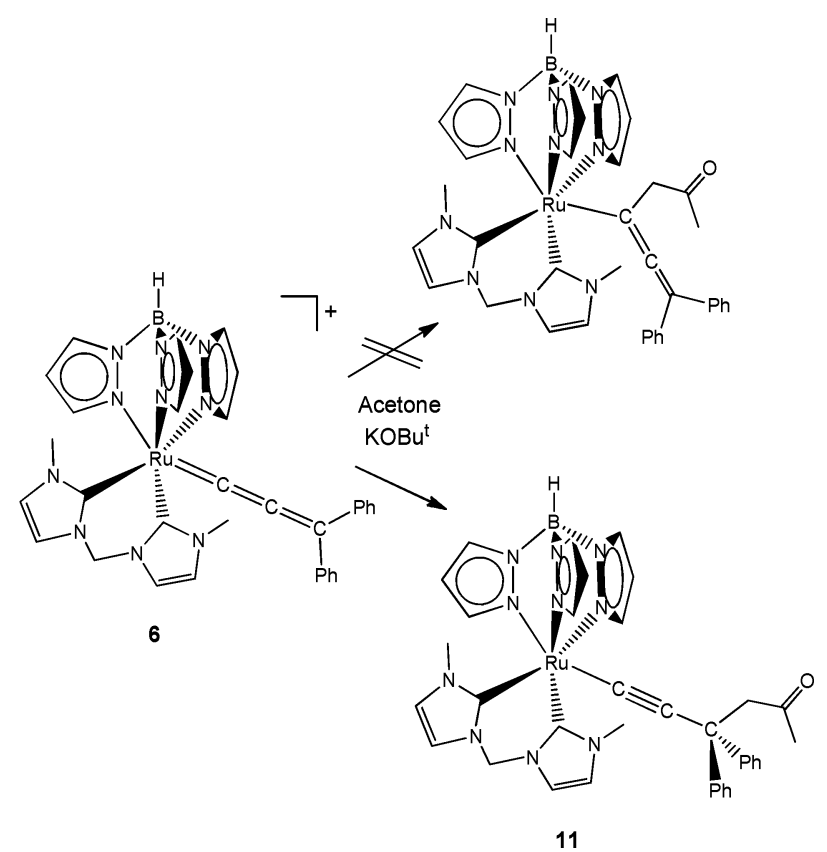

11 
dark green microcrystalline product was washed with petroleum ether and dried in vacuo. Yield: $0.84 \mathrm{~g}, 65 \%$. Anal. Calcd for $\mathrm{C}_{18} \mathrm{H}_{22} \mathrm{~N}_{10} \mathrm{BClRu}$. $0.25 \mathrm{C}_{2} \mathrm{H}_{4} \mathrm{Cl}_{2}$ : C, 40.36; H, 4.21; N, 25.44. Found: C, 40.21; H, 4.18, N, 25.20. IR: $\nu(\mathrm{BH}) 2453 \mathrm{~cm}^{-1}(\mathrm{~m}) .{ }^{1} \mathrm{H} \mathrm{NMR}\left(500 \mathrm{MHz}, \mathrm{CD}_{2} \mathrm{Cl}_{2}, 298 \mathrm{~K}\right)$ : $\delta 2.43\left(\mathrm{~s}, 6 \mathrm{H}, \mathrm{NCH}_{3}\right), 3.76\left(\mathrm{~s}, 1 \mathrm{H}, 0.25 \mathrm{C}_{2} \mathrm{H}_{4} \mathrm{Cl}_{2}\right), 5.61,7.35$ (d, ${ }^{2} J(\mathrm{HH})=11.5 \mathrm{~Hz}, 1 \mathrm{H}$ each, $\left.\mathrm{CH}_{a} H_{\mathrm{b}}\right), 5.92\left(\mathrm{t},{ }^{3} J(\mathrm{HH})=2.1 \mathrm{~Hz}, 1 \mathrm{H}\right)$, $6.08\left(\mathrm{~d},{ }^{3} \mathrm{~J}(\mathrm{HH})=1.9 \mathrm{~Hz}, 1 \mathrm{H}\right), 6.20\left(\mathrm{t},{ }^{3} \mathrm{~J}(\mathrm{HH})=2.1 \mathrm{~Hz}, 1 \mathrm{H}\right), 7.75(\mathrm{~d}$, $\left.{ }^{3} J(\mathrm{HH})=2.4 \mathrm{~Hz}, 1 \mathrm{H}\right), 7.77\left(\mathrm{~d},{ }^{3} \mathrm{~J}(\mathrm{HH})=1.9 \mathrm{~Hz}, 2 \mathrm{H}\right), 7.78\left(\mathrm{~d},{ }^{3} \mathrm{~J}(\mathrm{HH})=\right.$ $2.2 \mathrm{~Hz}, 2 \mathrm{H})(\mathrm{Tp}), 6.75,7.15\left(\mathrm{~d},{ }^{3} \mathrm{~J}(\mathrm{HH})=2 \mathrm{~Hz}, 2 \mathrm{H}\right.$ each, $\left.\mathrm{CH}=\mathrm{CH}\right)$. ${ }^{13} \mathrm{C}\left\{{ }^{1} \mathrm{H}\right\}$ NMR $\left(125 \mathrm{MHz}, \mathrm{CD}_{2} \mathrm{Cl}_{2}, 298 \mathrm{~K}\right): \delta 35.4\left(\mathrm{NCH}_{3}\right), 44.3(0.25$ $\left.\mathrm{C}_{2} \mathrm{H}_{4} \mathrm{Cl}_{2}\right), 63.5\left(\mathrm{CH}_{2}\right), 105.3,105.8,134.5,135.6,143.7,144.7(\mathrm{Tp})$, $120.4,121.6(\mathrm{CH}=\mathrm{CH}), 197.0(\mathrm{RuC})$.

$\left[\mathrm{TpRu}\left(\mathrm{N}_{2}\right)(\mathrm{L})\right]\left[\mathrm{BAr}^{\prime}{ }_{4}\right]\left(\mathbf{2}^{\prime}\right)$. A Fischer-Porter vessel was charged with $1(0.63 \mathrm{~g}, 1.18 \mathrm{mmol})$ and $\mathrm{NaBAr}_{4}^{\prime}(1.05 \mathrm{~g}, 1.19 \mathrm{mmol})$. The system was deoxygenated and placed under dinitrogen. Deoxygenated fluorobenzene $(12 \mathrm{~mL})$ was added. The reactor was then pressurized with $3.6 \mathrm{~atm}$ of dinitrogen, and the mixture was stirred at room temperature for $1 \mathrm{~h}$. At the end of this time, the excess pressure was relieved. The resulting yellow-brown suspension was filtered through Celite. The solvent was removed in vacuo, and the residue was triturated with petroleum ether until a brown powder was obtained. It was filtered off, washed with petroleum ether, and dried in vacuo. NMR indicated that this material contains more than $85 \%$ of the terminal dinitrogen complex 2 , plus a smaller amount (less than 15\%) of the bridging dinitrogen complex $\mathbf{2}^{\prime}$. For this reason, the content of $\mathrm{N}$ determined by microanalysis tends to be lower than expected. Yield: $1.35 \mathrm{~g}, 83 \%$. Anal. Calcd for $\mathrm{C}_{50} \mathrm{H}_{34} \mathrm{~N}_{12} \mathrm{~B}_{2} \mathrm{~F}_{24} \mathrm{Ru}$ : C, 43.47; H, 2.48; N, 12.17. Found: C, 43.35; $\mathrm{H}$, 2.39, N, 11.60. IR: $\nu(\mathrm{BH}) 2496 \mathrm{~cm}^{-1}(\mathrm{~m}), \nu(\mathrm{N} \equiv \mathrm{N}) 2154 \mathrm{~cm}^{-1}(\mathrm{~s}) .{ }^{1} \mathrm{H}$ NMR (500 MHz, $\left.\mathrm{CD}_{2} \mathrm{Cl}_{2}, 298 \mathrm{~K}\right): \delta 2.45\left(\mathrm{~s}, 6 \mathrm{H}, \mathrm{NCH}_{3}\right), 5.89,6.17$ (d, ${ }^{2} J(\mathrm{HH})=13.7 \mathrm{~Hz}, 1 \mathrm{H}$ each, $\left.\mathrm{CH}_{a} H_{\mathrm{b}}\right), 6.09\left(\mathrm{t},{ }^{3} J(\mathrm{HH})=2.3 \mathrm{~Hz}, 1 \mathrm{H}\right)$, $6.20\left(\mathrm{~d},{ }^{3} J(\mathrm{HH})=2.2 \mathrm{~Hz}, 2 \mathrm{H}\right), 6.35\left(\mathrm{t},{ }^{3} J(\mathrm{HH})=2.2 \mathrm{~Hz}, 2 \mathrm{H}\right), 7.66$ $\left(\mathrm{d},{ }^{3} \mathrm{~J}(\mathrm{HH})=1.9 \mathrm{~Hz}, 1 \mathrm{H}\right), 7.84\left(\mathrm{~d},{ }^{3} J(\mathrm{HH})=2.4 \mathrm{~Hz}, 1 \mathrm{H}\right), 7.87(\mathrm{~d}$, $\left.{ }^{3} \mathrm{~J}(\mathrm{HH})=2.4 \mathrm{~Hz}, 2 \mathrm{H}\right)(\mathrm{Tp}), 6.87,7.25\left(\mathrm{~d},{ }^{3} \mathrm{~J}(\mathrm{HH})=2.1 \mathrm{~Hz}, 2 \mathrm{H}\right.$ each, $\mathrm{CH}=\mathrm{CH}) .{ }^{13} \mathrm{C}\left\{{ }^{1} \mathrm{H}\right\} \mathrm{NMR}\left(125 \mathrm{MHz}, \mathrm{CD}_{2} \mathrm{Cl}_{2}, 298 \mathrm{~K}\right): \delta 36.1\left(\mathrm{NCH}_{3}\right)$, 63.4 $\left(\mathrm{CH}_{2}\right), 107.0,107.1,136.6,137.0,143.5,143.9(\mathrm{Tp}), 121.7,123.9$ $(\mathrm{CH}=\mathrm{CH}), 183.1(\mathrm{RuC})$.

$\left[\{T p R u(L)\}_{2}\left(\mu-N_{2}\right)\right]\left[B A r^{\prime}\right]_{2}$ (2). Recrystallization of the terminal dinitrogen complex $\mathbf{2}^{\prime}$ from dichloromethane/petroleum ether under an atmosphere of dinitrogen or argon afforded greenish gray crystals of the bridging dinitrogen complex 2 . The crystals were filtered off and dried in vacuo: Yield: $66 \%$. Anal. Calcd for $\mathrm{C}_{100} \mathrm{H}_{68} \mathrm{~N}_{22} \mathrm{~B}_{4} \mathrm{~F}_{48} \mathrm{Ru}_{2}$ : C, 43.91; $\mathrm{H}, 2.51$; $\mathrm{N}, 11.27$. Found: C, $44.01 ; \mathrm{H}, 2.55$, N, 11.18. IR: $\nu(\mathrm{BH}) 2496 \mathrm{~cm}^{-1}(\mathrm{~m})$. Raman: $\nu(\mathrm{N} \equiv \mathrm{N}) 2106 \mathrm{~cm}^{-1}(\mathrm{~s}) .{ }^{1} \mathrm{H} \mathrm{NMR}\left(500 \mathrm{MHz}, \mathrm{CD}_{2} \mathrm{Cl}_{2}, 298 \mathrm{~K}\right)$ : $\delta 2.44\left(\mathrm{~s}, 12 \mathrm{H}, \mathrm{NCH}_{3}\right), 4.65,5.08\left(\mathrm{~d},{ }^{2} \mathrm{~J}(\mathrm{HH})=13.6 \mathrm{~Hz}, 2 \mathrm{H}\right.$ each, $\left.\mathrm{CH}_{a} H_{\mathrm{b}}\right), 6.11\left(\mathrm{t},{ }^{3} \mathrm{~J}(\mathrm{HH})=2.2 \mathrm{~Hz}, 2 \mathrm{H}\right), 6.21\left(\mathrm{t},{ }^{3} \mathrm{~J}(\mathrm{HH})=2.2 \mathrm{~Hz}, 4 \mathrm{H}\right)$, $6.25\left(\mathrm{~d},{ }^{3} \mathrm{~J}(\mathrm{HH})=2.1 \mathrm{~Hz}, 2 \mathrm{H}\right), 7.15\left(\mathrm{~d},{ }^{3} \mathrm{~J}(\mathrm{HH})=1.9 \mathrm{~Hz}, 4 \mathrm{H}\right), 7.86$ $\left(\mathrm{d},{ }^{3} J(\mathrm{HH})=2.4 \mathrm{~Hz}, 2 \mathrm{H}\right), 7.90\left(\mathrm{~d},{ }^{3} J(\mathrm{HH})=2.4 \mathrm{~Hz}, 4 \mathrm{H}\right)$ (Tp), 6.80, $6.94\left(\mathrm{~d},{ }^{3} \mathrm{~J}(\mathrm{HH})=2.1 \mathrm{~Hz}, 4 \mathrm{H}\right.$ each, $\left.\mathrm{CH}=\mathrm{CH}\right) .{ }^{13} \mathrm{C}\left\{{ }^{1} \mathrm{H}\right\}$ NMR $\left(125 \mathrm{MHz}, \mathrm{CD}_{2} \mathrm{Cl}_{2}, 298 \mathrm{~K}\right): \delta 36.1\left(\mathrm{NCH}_{3}\right), 62.0\left(\mathrm{CH}_{2}\right)$, 107.1, 107.6, 137.1, 137.8, 142.2, $144.3(\mathrm{Tp}), 121.7,123.9(\mathrm{CH}=\mathrm{CH})$, $182.0(\mathrm{RuC})$.

$[\mathrm{TpRu}(\mathrm{CO})(\mathrm{L})]\left[\mathrm{BAr}_{4}{ }_{4}\right]$ (3). CO was bubbled through a dichloromethane solution containing a mixture of $\mathbf{2}$ and $\mathbf{2}^{\prime}(0.1 \mathrm{~g})$. The mixture was stirred for $18 \mathrm{~h}$ under $\mathrm{CO}$ at room temperature. Then, the solvent was removed in vacuo, and the brown residue was washed with petroleum ether and dried. Yield: $0.096 \mathrm{~g}, 96 \%$. Anal. Calcd for $\mathrm{C}_{51} \mathrm{H}_{34} \mathrm{~N}_{10} \mathrm{~B}_{2} \mathrm{~F}_{24} \mathrm{ORu}$ : C, 44.34; H, 2.48; N, 10.14. Found: C, 44.45; H, 2.56, N, 10.05. IR: $\nu(\mathrm{BH}) 2496 \mathrm{~cm}^{-1}(\mathrm{~m}), \nu(\mathrm{CO}) 1965 \mathrm{~cm}^{-1}(\mathrm{~s}) .{ }^{1} \mathrm{H}$ NMR (500 MHz, $\left.\mathrm{CD}_{2} \mathrm{Cl}_{2}, 298 \mathrm{~K}\right): \delta 2.49\left(\mathrm{~s}, 6 \mathrm{H}, \mathrm{NCH}_{3}\right), 5.87,6.24(\mathrm{~d}$, ${ }^{2} J(\mathrm{HH})=13.6 \mathrm{~Hz}, 1 \mathrm{H}$ each, $\left.\mathrm{CH}_{a} H_{\mathrm{b}}\right), 6.18\left(\mathrm{t},{ }^{3} \mathrm{~J}(\mathrm{HH})=2.3 \mathrm{~Hz}, 1 \mathrm{H}\right)$, $6.31\left(\mathrm{t},{ }^{3} \mathrm{~J}(\mathrm{HH})=2.2 \mathrm{~Hz}, 2 \mathrm{H}\right), 6.43\left(\mathrm{~d},{ }^{3} \mathrm{~J}(\mathrm{HH})=2 \mathrm{~Hz}, 1 \mathrm{H}\right), 7.66$ $\left(\mathrm{d},{ }^{3} \mathrm{~J}(\mathrm{HH})=1.9 \mathrm{~Hz}, 2 \mathrm{H}\right), 7.84\left(\mathrm{~d},{ }^{3} J(\mathrm{HH})=2.4 \mathrm{~Hz}, 2 \mathrm{H}\right), 7.86(\mathrm{~d}$, $\left.{ }^{3} \mathrm{~J}(\mathrm{HH})=2.4 \mathrm{~Hz}, 1 \mathrm{H}\right)(\mathrm{Tp}), 6.86,7.23\left(\mathrm{~d},{ }^{3} \mathrm{~J}(\mathrm{HH})=2.1 \mathrm{~Hz}, 2 \mathrm{H}\right.$ each, $\mathrm{CH}=\mathrm{CH}) .{ }^{13} \mathrm{C}\left\{{ }^{1} \mathrm{H}\right\} \mathrm{NMR}\left(125 \mathrm{MHz}, \mathrm{CD}_{2} \mathrm{Cl}_{2}, 298 \mathrm{~K}\right): \delta 36.4\left(\mathrm{NCH}_{3}\right)$, $63.9\left(\mathrm{CH}_{2}\right), 107.0,107.3,136.7,137.0,142.6,145.1(\mathrm{Tp}), 121.6,124.1$ $(\mathrm{CH}=\mathrm{CH}), 179.3(\mathrm{RuC}), 203.0(\mathrm{RuCO})$.

$\left[\mathrm{TpRu}=\mathrm{C}=\mathrm{CHC}(\mathrm{OMe}) \mathrm{RR}^{\prime}(\mathrm{L})\right]\left[\mathrm{BPh}_{4}\right]\left(\mathrm{RR}^{\prime}=\mathrm{Me}_{2}(4 \mathrm{a}),\left(\mathrm{CH}_{2}\right)_{5}\right.$ (4b), MePh (4c), HPh (4d)). To a mixture of $1(0.16 \mathrm{~g}, 0.3 \mathrm{mmol})$ and $\mathrm{NaBPh}_{4}(0.2 \mathrm{~g}$, excess $)$ in $\mathrm{MeOH}(8 \mathrm{~mL})$ under dinitrogen was added a slight excess of the corresponding propargyl alcohol $\mathrm{HC} \equiv \mathrm{CC}(\mathrm{OH}) \mathrm{RR}^{\prime}$. The mixture was stirred at $60^{\circ} \mathrm{C}$ for $1 \mathrm{~h}$. During this time, a microcrystalline precipitate was formed. After the mixture was cooled to room temperature, the solids were filtered off, washed with ethanol and petroleum ether, and dried in vacuo. Recrystallization from dichloromethane/petroleum ether afforded the corresponding $\gamma$--methoxyvinylidene complexes in analytically pure form. Data for $\mathbf{4 a}$ are as follows. Yield: $0.19 \mathrm{~g}, 73 \%$. Anal. Calcd for $\mathrm{C}_{47} \mathrm{H}_{50} \mathrm{~N}_{10} \mathrm{~B}_{2} \mathrm{ORu}$ : C, 63.17; H, 5.64; $\mathrm{N}$, 15.67. Found: C, 63.15; H, 5.66, N, 15.55. IR: $\nu(\mathrm{BH}) 2478 \mathrm{~cm}^{-1}(\mathrm{~m})$, $\nu(\mathrm{C}=\mathrm{C}) 1634 \mathrm{~cm}^{-1}(\mathrm{~m}) .{ }^{1} \mathrm{H}$ NMR $\left(500 \mathrm{MHz}, \mathrm{CD}_{2} \mathrm{Cl}_{2}, 298 \mathrm{~K}\right): \delta 1.28$ $\left(\mathrm{s}, 6 \mathrm{H}, \mathrm{C}\left(\mathrm{CH}_{3}\right)_{2}\right), 2.33\left(\mathrm{~s}, 6 \mathrm{H}, \mathrm{NCH}_{3}\right), 3.09\left(\mathrm{~s}, 3 \mathrm{OCH}_{3}\right), 3.91(\mathrm{~s}, 1 \mathrm{H}$, $\mathrm{Ru}=\mathrm{C}=\mathrm{CH}), 5.25,6.80\left(\mathrm{~d},{ }^{2} J(\mathrm{HH})=13 \mathrm{~Hz}, 1 \mathrm{H}\right.$ each, $\left.\mathrm{CH}_{a} H_{\mathrm{b}}\right), 6.25$ $\left(\mathrm{t},{ }^{3} \mathrm{~J}(\mathrm{HH})=2.1 \mathrm{~Hz}, 1 \mathrm{H}\right), 6.29\left(\mathrm{t},{ }^{3} \mathrm{~J}(\mathrm{HH})=2.2 \mathrm{~Hz}, 2 \mathrm{H}\right), 6.60(\mathrm{~d}$, $\left.{ }^{3} J(\mathrm{HH})=2 \mathrm{~Hz}, 1 \mathrm{H}\right), 7.53\left(\mathrm{~d},{ }^{3} J(\mathrm{HH})=2 \mathrm{~Hz}, 2 \mathrm{H}\right), 7.84\left(\mathrm{~d},{ }^{3} \mathrm{~J}(\mathrm{HH})=\right.$ $2.4 \mathrm{~Hz}, 2 \mathrm{H}), 7.93\left(\mathrm{~d},{ }^{3} J(\mathrm{HH})=2.3 \mathrm{~Hz}, 1 \mathrm{H}\right)(\mathrm{Tp}), 6.66,6.88\left(\mathrm{~d},{ }^{3} J(\mathrm{HH})=\right.$ $2 \mathrm{~Hz}, 2 \mathrm{H}$ each, $\mathrm{CH}=\mathrm{CH}) .{ }^{13} \mathrm{C}\left\{{ }^{1} \mathrm{H}\right\} \mathrm{NMR}\left(125 \mathrm{MHz}, \mathrm{CD}_{2} \mathrm{Cl}_{2}, 298 \mathrm{~K}\right): \delta$ $28.9\left(\mathrm{C}\left(\mathrm{CH}_{3}\right)_{2}\right), 36.2\left(\mathrm{NCH}_{3}\right), 50.5\left(\mathrm{OCH}_{3}\right), 63.4\left(\mathrm{CH}_{2}\right), 74.3$ $\left(\mathrm{C}\left(\mathrm{CH}_{3}\right)_{2}\right), 114.1 \quad(\mathrm{Ru}=\mathrm{C}=\mathrm{CH}), 106.6,107.4,136.4,136.7,143.2$, $144.6(\mathrm{Tp}), 122.0,123.4(\mathrm{CH}=\mathrm{CH}), 177.6(\mathrm{RuC}), 352.6(\mathrm{Ru}=\mathrm{C}=$ $\mathrm{CH})$. Data for $\mathbf{4 b}$ are as follows. Yield: $0.22 \mathrm{~g}, 79 \%$. Anal. Calcd for $\mathrm{C}_{50} \mathrm{H}_{54} \mathrm{~N}_{10} \mathrm{~B}_{2} \mathrm{ORu}$ : C, 64.32; H, 5.83; N, 15.00. Found: C, 64.29; H, 5.72, N, 14.85. IR: $\nu(\mathrm{BH}) 2476 \mathrm{~cm}^{-1}(\mathrm{~m}), \nu(\mathrm{C}=\mathrm{C}) 1642 \mathrm{~cm}^{-1}(\mathrm{~m}) .{ }^{1} \mathrm{H}$ NMR $\left(500 \mathrm{MHz}, \mathrm{CD}_{2} \mathrm{Cl}_{2}, 298 \mathrm{~K}\right): \delta 1.29-1.63\left(\mathrm{~m}, 10 \mathrm{H}, \mathrm{C}\left(\mathrm{CH}_{2}\right)_{5}\right), 2.31$ $\left(\mathrm{s}, 6 \mathrm{H}, \mathrm{NCH}_{3}\right), 3.00\left(\mathrm{~s}, 3 \mathrm{OCH}_{3}\right), 3.70(\mathrm{~s}, 1 \mathrm{H}, \mathrm{Ru}=\mathrm{C}=\mathrm{CH}), 5.24,6.84$ $\left(\mathrm{d},{ }^{2} J(\mathrm{HH})=12.7 \mathrm{~Hz}, 1 \mathrm{H}\right.$ each, $\left.\mathrm{CH}_{a} H_{\mathrm{b}}\right), 6.22\left(\mathrm{t},{ }^{3} J(\mathrm{HH})=2.2 \mathrm{~Hz}, 1 \mathrm{H}\right)$, $6.27\left(\mathrm{t},{ }^{3} \mathrm{~J}(\mathrm{HH})=2.2 \mathrm{~Hz}, 2 \mathrm{H}\right), 6.56\left(\mathrm{~d},{ }^{3} J(\mathrm{HH})=2 \mathrm{~Hz}, 1 \mathrm{H}\right), 7.54(\mathrm{~d}$, $\left.{ }^{3} J(\mathrm{HH})=2 \mathrm{~Hz}, 2 \mathrm{H}\right), 7.82\left(\mathrm{~d},{ }^{3} \mathrm{~J}(\mathrm{HH})=2.4 \mathrm{~Hz}, 2 \mathrm{H}\right), 7.91\left(\mathrm{~d},{ }^{3} \mathrm{~J}(\mathrm{HH})=\right.$ $2.3 \mathrm{~Hz}, 1 \mathrm{H})(\mathrm{Tp}), 6.67,6.88\left(\mathrm{~d},{ }^{3} \mathrm{~J}(\mathrm{HH})=2 \mathrm{~Hz}, 2 \mathrm{H}\right.$ each, $\left.\mathrm{CH}=\mathrm{CH}\right)$. ${ }^{13} \mathrm{C}\left\{{ }^{1} \mathrm{H}\right\} \mathrm{NMR}\left(125 \mathrm{MHz}, \mathrm{CD}_{2} \mathrm{Cl}_{2}, 298 \mathrm{~K}\right): \delta 22.8,25.8,37.9\left(\mathrm{C}\left(\mathrm{CH}_{2}\right)_{5}\right)$,

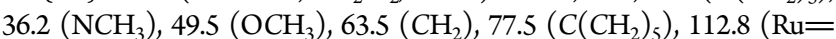
$\mathrm{C}=\mathrm{CH}), 106.5,107.4,136.3,136.7,143.1,144.6(\mathrm{Tp}), 122.0,123.5$ $(\mathrm{CH}=\mathrm{CH}), 177.8(\mathrm{RuC}), 352.3(\mathrm{Ru}=\mathrm{C}=\mathrm{CH})$. Data for $4 \mathrm{c}$ are as follows. Yield: $0.24 \mathrm{~g}, 84 \%$. Anal. Calcd for $\mathrm{C}_{52} \mathrm{H}_{52} \mathrm{~N}_{10} \mathrm{~B}_{2} \mathrm{ORu}$ : C, 65.35; $\mathrm{H}$, 5.48; N, 14.66. Found: C, 65.45; H, 5.41, N, 14.56. IR: $\nu(\mathrm{BH}) 2519$, $2489 \mathrm{~cm}^{-1}(\mathrm{~m}), \nu(\mathrm{C}=\mathrm{C}) 1636 \mathrm{~cm}^{-1}(\mathrm{~m}) .{ }^{1} \mathrm{H}$ NMR $\left(500 \mathrm{MHz}, \mathrm{CD}_{2} \mathrm{Cl}_{2}\right.$, $298 \mathrm{~K}): \delta 1.52\left(\mathrm{~s}, 3 \mathrm{H}, \mathrm{C}\left(\mathrm{OCH}_{3}\right) \mathrm{CH}_{3} \mathrm{C}_{6} \mathrm{H}_{5}\right), 2.25,2.30$ (s, $3 \mathrm{H}$ each, $\left.\mathrm{NCH}_{3}\right), 2.94\left(\mathrm{~s}, 3 \mathrm{H}, \mathrm{OCH}_{3}\right), 4.13(\mathrm{~s}, 1 \mathrm{H}, \mathrm{Ru}=\mathrm{C}=\mathrm{CH}), 5.31,6.93(\mathrm{~d}$, ${ }^{2} J(\mathrm{HH})=13.4 \mathrm{~Hz}, 1 \mathrm{H}$ each, $\left.\mathrm{CH}_{a} H_{\mathrm{b}}\right), 6.12(\mathrm{t} \mathrm{br}, 1 \mathrm{H}), 6.23(\mathrm{t} \mathrm{br}, 2 \mathrm{H})$, $6.59(\mathrm{~d} \mathrm{br}, 1 \mathrm{H}), 6.65(\mathrm{~d} \mathrm{br}, 1 \mathrm{H}), 7.22(\mathrm{~d} \mathrm{br}, 1 \mathrm{H}), 7.76\left(\mathrm{~d},{ }^{3} J(\mathrm{HH})=\right.$ $2.3 \mathrm{~Hz}, 1 \mathrm{H}), 7.80(\mathrm{~d} \mathrm{br}, 1 \mathrm{H}), 7.90\left(\mathrm{~d},{ }^{3} \mathrm{~J}(\mathrm{HH})=2.3 \mathrm{~Hz}, 1 \mathrm{H}\right),(\mathrm{Tp}), 6.68$, 6.72, 6.85, $6.87\left(\mathrm{~d},{ }^{3} \mathrm{~J}(\mathrm{HH})=2 \mathrm{~Hz}, 1 \mathrm{H}\right.$ each, $\left.\mathrm{CH}=\mathrm{CH}\right), 6.93,7.23,7.33$ $\left(\mathrm{m}, 5 \mathrm{H}, \mathrm{C}_{6} \mathrm{H}_{5}\right) \cdot{ }^{13} \mathrm{C}\left\{{ }^{1} \mathrm{H}\right\}$ NMR $\left(125 \mathrm{MHz}, \mathrm{CD}_{2} \mathrm{Cl}_{2}, 298 \mathrm{~K}\right): \delta 31.1$ $\left(\mathrm{C}\left(\mathrm{CH}_{3}\right) \mathrm{C}_{6} \mathrm{H}_{5}\right), 36.1,36.3\left(\mathrm{NCH}_{3}\right), 51.3\left(\mathrm{OCH}_{3}\right), 63.5\left(\mathrm{CH}_{2}\right), 79.6$ $\left(\mathrm{C}\left(\mathrm{OCH}_{3}\right) \mathrm{CH}_{3} \mathrm{C}_{6} \mathrm{H}_{5}\right), 113.9(\mathrm{Ru}=\mathrm{C}=\mathrm{CH}), 106.4,106.6,107.5,136.2$, $136.3,136.8,143.3,144.4,144.98(\mathrm{Tp}), 122.1,122.2,123.5,123.6(\mathrm{CH}=$ $\mathrm{CH}), 126.3,127.7,128.4\left(\mathrm{C}_{6} \mathrm{H}_{5}\right), 177.1,177.7(\mathrm{RuC}), 351.1(\mathrm{Ru}=\mathrm{C}=$ $\mathrm{CH})$. Data for $4 \mathrm{~d}$ are as follows. Yield: $0.19 \mathrm{~g}, 69 \%$. Anal. Calcd for $\mathrm{C}_{51} \mathrm{H}_{50} \mathrm{~N}_{10} \mathrm{~B}_{2} \mathrm{ORu}: \mathrm{C}, 65.05 ; \mathrm{H}, 5.35 ; \mathrm{N}, 14.87$. Found: $\mathrm{C}, 64.87 ; \mathrm{H}, 5.19$, N, 14.50. IR: $\nu(\mathrm{BH}) 2486 \mathrm{~cm}^{-1}(\mathrm{~m}), \nu(\mathrm{C}=\mathrm{C}) 1642 \mathrm{~cm}^{-1}(\mathrm{~m}) .{ }^{1} \mathrm{H}$ NMR $\left(500 \mathrm{MHz}, \mathrm{CDCl}_{3}, 298 \mathrm{~K}\right): \delta 2.22,2.23\left(\mathrm{~s}, 3 \mathrm{H}\right.$ each, $\left.\mathrm{NCH}_{3}\right), 3.10(\mathrm{~s}, 3 \mathrm{H}$, $\left.\mathrm{OCH}_{3}\right), 4.12\left(\mathrm{~d},{ }^{3} \mathrm{~J}(\mathrm{HH})=7.5 \mathrm{~Hz}, 1 \mathrm{H}, \mathrm{CH}\left(\mathrm{OCH}_{3}\right), 4.87\left(\mathrm{~d},{ }^{3} J(\mathrm{HH})=\right.\right.$ $7.5 \mathrm{~Hz}, 1 \mathrm{H}, \mathrm{Ru}=\mathrm{C}=\mathrm{CH}), 4.54,6.23\left(\mathrm{~d},{ }^{2} J(\mathrm{HH})=13.3 \mathrm{~Hz}, 1 \mathrm{H}\right.$ each, $\left.\mathrm{CH}_{a} H_{\mathrm{b}}\right), 6.12\left(\mathrm{t},{ }^{3} J(\mathrm{HH})=2.2 \mathrm{~Hz}, 1 \mathrm{H}\right), 6.19\left(\mathrm{t},{ }^{3} J(\mathrm{HH})=2.1 \mathrm{~Hz}, 2 \mathrm{H}\right)$, $6.52\left(\mathrm{~d},{ }^{3} J(\mathrm{HH})=1.9 \mathrm{~Hz}, 1 \mathrm{H}\right), 7.28\left(\mathrm{~d},{ }^{3} \mathrm{~J}(\mathrm{HH})=2 \mathrm{~Hz}, 1 \mathrm{H}\right), 7.70(\mathrm{~d}$, $\left.{ }^{3} J(\mathrm{HH})=2.4 \mathrm{~Hz}, 1 \mathrm{H}\right), 7.72\left(\mathrm{~d},{ }^{3} J(\mathrm{HH})=2.3 \mathrm{~Hz}, 1 \mathrm{H}\right), 7.83\left(\mathrm{~d},{ }^{3} \mathrm{~J}(\mathrm{HH})=\right.$ $2.3 \mathrm{~Hz}, 1 \mathrm{H}),(\mathrm{Tp}), 6.42,6.44,6.52,6.55\left(\mathrm{~d},{ }^{3} J(\mathrm{HH})=2 \mathrm{~Hz}, 1 \mathrm{H}\right.$ each, $\mathrm{CH}=\mathrm{CH}), 7.27-7.101\left(\mathrm{~m}, 5 \mathrm{H}, \mathrm{C}_{6} \mathrm{H}_{5}\right) .{ }^{13} \mathrm{C}\left\{{ }^{1} \mathrm{H}\right\}$ NMR $(125 \mathrm{MHz}$, $\left.\mathrm{CDCl}_{3}, 298 \mathrm{~K}\right): \delta 35.7\left(\mathrm{NCH}_{3}\right), 56.1\left(\mathrm{OCH}_{3}\right), 62.5\left(\mathrm{CH}_{2}\right), 75.5$ $\left(\mathrm{CH}\left(\mathrm{OCH}_{3}\right)\right), 110.4(\mathrm{Ru}=\mathrm{C}=\mathrm{CH}), 106.1,106.3,107.3,135.7,135.8$, $136.1,142.8,144.0,144.5(\mathrm{Tp}), 122.2,122.3,122.6,122.7(\mathrm{CH}=\mathrm{CH})$, 126.1, 128.0, $128.5\left(\mathrm{C}_{6} \mathrm{H}_{5}\right), 175.7,175.9(\mathrm{RuC}), 351.0(\mathrm{Ru}=\mathrm{C}=\mathrm{CH})$.

$\left[\mathrm{TpRu}=\mathrm{C}=\mathrm{CHCH}_{2} \mathrm{OH}(\mathrm{L})\right]\left[\mathrm{BPh}_{4}\right]$ (5). This compound was obtained in a fashion analogous to that for $\mathbf{4 a}-\mathbf{d}$, starting from $\mathbf{1}(0.16 \mathrm{~g}$, $0.3 \mathrm{mmol}$ ) and the appropriate amounts of $\mathrm{NaBPh}_{4}$ and $\mathrm{HC} \equiv \mathrm{CCH}_{2} \mathrm{OH}$ in MeOH. Yield: $0.19 \mathrm{~g}, 73 \%$. Anal. Calcd for $\mathrm{C}_{45} \mathrm{H}_{46} \mathrm{~N}_{10} \mathrm{~B} 2 \mathrm{ORu}$ : C, 62.44; $\mathrm{H}, 5.36$; N, 16.18. Found: C, 62.32; H, 5.29, N, 15.92. IR: $\nu(\mathrm{BH})$ $2488 \mathrm{~cm}^{-1}(\mathrm{~m}), \nu(\mathrm{C}=\mathrm{C}) 1654 \mathrm{~cm}^{-1}(\mathrm{~m}), \nu(\mathrm{OH}) 3543 \mathrm{~cm}^{-1}(\mathrm{~m}) .{ }^{1} \mathrm{H}$ NMR $\left(500 \mathrm{MHz}, \mathrm{SO}\left(\mathrm{CD}_{3}\right)_{2}, 298 \mathrm{~K}\right): \delta 2.29\left(\mathrm{~s}, 6 \mathrm{H}, \mathrm{NCH}_{3}\right), 4.13$ $\left(\mathrm{d},{ }^{3} \mathrm{~J}(\mathrm{HH})=8.4 \mathrm{~Hz}, 2 \mathrm{H}, \mathrm{CH}_{2} \mathrm{OH}\right), 4.40\left(\mathrm{~d},{ }^{3} \mathrm{~J}(\mathrm{HH})=8.4 \mathrm{~Hz}, 1 \mathrm{H}\right.$, 
$\mathrm{Ru}=\mathrm{C}=\mathrm{CH}), 6.40,6.81\left(\mathrm{~d},{ }^{2} J(\mathrm{HH})=13.2 \mathrm{~Hz}, 1 \mathrm{H}\right.$ each, $\left.\mathrm{CH}_{a} H_{\mathrm{b}}\right), 6.28$ $\left(\mathrm{t},{ }^{3} \mathrm{~J}(\mathrm{HH})=2.1 \mathrm{~Hz}, 1 \mathrm{H}\right), 6.30\left(\mathrm{t},{ }^{3} \mathrm{~J}(\mathrm{HH})=2.2 \mathrm{~Hz}, 2 \mathrm{H}\right), 6.69(\mathrm{~d}$, $\left.{ }^{3} \mathrm{~J}(\mathrm{HH})=1.9 \mathrm{~Hz}, 1 \mathrm{H}\right), 7.55\left(\mathrm{~d},{ }^{3} \mathrm{~J}(\mathrm{HH})=1.9 \mathrm{~Hz}, 2 \mathrm{H}\right), 7.99\left(\mathrm{~d},{ }^{3} \mathrm{~J}(\mathrm{HH})=\right.$ $2.4 \mathrm{~Hz}, 2 \mathrm{H}), 8.13\left(\mathrm{~d},{ }^{3} \mathrm{~J}(\mathrm{HH})=2.3 \mathrm{~Hz}, 1 \mathrm{H}\right)(\mathrm{Tp}), 7.21,7.65\left(\mathrm{~d},{ }^{3} \mathrm{~J}(\mathrm{HH})=\right.$ $2 \mathrm{~Hz}, 2 \mathrm{H}$ each, $\mathrm{CH}=\mathrm{CH}) .{ }^{13} \mathrm{C}\left\{{ }^{1} \mathrm{H}\right\} \mathrm{NMR}\left(125 \mathrm{MHz}, \mathrm{SO}\left(\mathrm{CD}_{3}\right)_{2}\right.$, $298 \mathrm{~K}): \delta 35.2\left(\mathrm{NCH}_{3}\right), 50.7\left(\mathrm{CH}_{2} \mathrm{OH}\right), 62.3\left(\mathrm{CH}_{2}\right), 106.7(\mathrm{Ru}=\mathrm{C}=\mathrm{CH})$, 106.5, 107.0, 136.2, 136.8, 143.1, 144.6 (Tp), 121.8, $123.4(\mathrm{CH}=\mathrm{CH}), 183.7$ $(\mathrm{RuC}), 352.5(\mathrm{Ru}=\mathrm{C}=\mathrm{CH})$.

$\left[\mathrm{TpRu}=\mathrm{C}=\mathrm{C}=\mathrm{CPh}_{2}(\mathrm{~L})\right]\left[\mathrm{BPh}_{4}\right]$ (6). To a mixture of 1 (0.26 g, $0.5 \mathrm{mmol}), \mathrm{NaBPh}_{4}(0.3 \mathrm{~g}$, excess $)$, and $\mathrm{HC} \equiv \mathrm{CC}(\mathrm{OH}) \mathrm{Ph}_{2}(0.12 \mathrm{~g}$, $0.6 \mathrm{mmol})$ was added $\mathrm{MeOH}(10 \mathrm{~mL})$. The mixture was stirred at $60^{\circ} \mathrm{C}$ for $1 \mathrm{~h}$. During this time, a purple microcrystalline precipitate was formed. After the mixture was cooled to room temperature, the solids were filtered off, washed with ethanol and petroleum ether, and dried in vacuo. The purple crystalline material was dissolved in 1,2-dichloroethane, and the solution was filtered. The solution was stirred at $80^{\circ} \mathrm{C}$ for $1 \mathrm{~h}$, in order to ensure complete dehydration of the intermediate $\gamma$-hydroxyvinylidene complex, always present in variable amounts. After the mixture was cooled to room temperature, the solvent was removed in vacuo. The residue was washed with petroleum ether and then stirred with $\mathrm{MeOH}$. The purple crystalline material was filtered off, washed with ethanol and petroleum ether, and dried in vacuo. The complex can be further purified by recrystallization from dichloromethane/petroleum ether. Yield: $0.35 \mathrm{~g}, 70 \%$. Anal. Calcd for $\mathrm{C}_{57} \mathrm{H}_{52} \mathrm{~N}_{10} \mathrm{~B}_{2} \mathrm{Ru}$ : C, 68.48; $\mathrm{H}$, 5.24; N, 14.01. Found: C, $68.51 ; \mathrm{H}, 5.19, \mathrm{~N}, 13.85$. IR: $\nu(\mathrm{BH}) 2479 \mathrm{~cm}^{-1}$ $(\mathrm{m}), \nu(\mathrm{C}=\mathrm{C}=\mathrm{C}) 1913 \mathrm{~cm}^{-1}(\mathrm{~s}) .{ }^{1} \mathrm{H}$ NMR $\left(500 \mathrm{MHz}, \mathrm{CDCl}_{3}, 298 \mathrm{~K}\right)$ : $\delta 2.38\left(\mathrm{~s}, 6 \mathrm{H}, \mathrm{NCH}_{3}\right), 5.30,6.43\left(\mathrm{~d},{ }^{2} J(\mathrm{HH})=12.7 \mathrm{~Hz}, 1 \mathrm{H}\right.$ each, $\left.\mathrm{CH}_{a} \mathrm{H}_{\mathrm{b}}\right), 6.18\left(\mathrm{t},{ }^{3} \mathrm{~J}(\mathrm{HH})=2.4 \mathrm{~Hz}, 2 \mathrm{H}\right), 6.36\left(\mathrm{t},{ }^{3} \mathrm{~J}(\mathrm{HH})=2.2 \mathrm{~Hz}, 1 \mathrm{H}\right)$, $6.84\left(\mathrm{~d},{ }^{3} \mathrm{~J}(\mathrm{HH})=2 \mathrm{~Hz}, 1 \mathrm{H}\right), 7.33\left(\mathrm{~d},{ }^{3} J(\mathrm{HH})=2 \mathrm{~Hz}, 2 \mathrm{H}\right), 7.80(\mathrm{~d}$, $\left.{ }^{3} J(\mathrm{HH})=2.4 \mathrm{~Hz}, 2 \mathrm{H}\right), 8.03\left(\mathrm{~d},{ }^{3} J(\mathrm{HH})=2.3 \mathrm{~Hz}, 1 \mathrm{H}\right)(\mathrm{Tp}), 6.70,7.17$ $\left(\mathrm{d},{ }^{3} \mathrm{~J}(\mathrm{HH})=2 \mathrm{~Hz}, 2 \mathrm{H}\right.$ each, $\left.\mathrm{CH}=\mathrm{CH}\right), 7.29,7.67,7.69(\mathrm{~m}, 10 \mathrm{H}$, $\left.\mathrm{C}_{6} \mathrm{H}_{5}\right) .{ }^{13} \mathrm{C}\left\{{ }^{1} \mathrm{H}\right\}$ NMR $\left(125 \mathrm{MHz}, \mathrm{CDCl}_{3}, 298 \mathrm{~K}\right): \delta 35.6\left(\mathrm{NCH}_{3}\right), 62.4$ $\left(\mathrm{CH}_{2}\right)$, 106.0, 107.5, 135.3, 137.2, 143.0, $143.8(\mathrm{Tp}), 121.7,122.1$ $(\mathrm{CH}=\mathrm{CH}), 129.1,129.2,130.0\left(\mathrm{C}_{6} \mathrm{H}_{5}\right), 145.8(\mathrm{RuC}=\mathrm{C}=\mathrm{C}), 176.8$ $(\mathrm{RuC}), 223.7(\mathrm{Ru}=\mathrm{C}=\mathrm{C}=\mathrm{C}), 306.0(\mathrm{RuC}=\mathrm{C}=\mathrm{C})$.

$\left[T p R u=C\left(C_{3} \mathrm{H}_{3} \mathrm{~N}_{2}\right) \mathrm{CH}=\mathrm{CPh}_{2}(\mathrm{~L})\right]\left[\mathrm{BPh}_{4}\right]$ (7). To a solution of the allenylidene complex $6(0.15 \mathrm{~g}, 0.15 \mathrm{mmol})$ in 1,2-dichloroethane $(8 \mathrm{~mL})$ was added pyrazole $(14 \mathrm{mg}, 0.2 \mathrm{mmol})$. The mixture was stirred at $80{ }^{\circ} \mathrm{C}$ for $18 \mathrm{~h}$. A dark green solution was obtained. The solvent was removed in vacuo, and the residue was washed thoroughly with petroleum ether and dried in vacuo. Recrystallization from dichloromethane/petroleum ether afforded well-formed green crystals of 7 containing one solvate molecule of $\mathrm{CH}_{2} \mathrm{Cl}_{2}$. The crystals were filtered off and dried in vacuo. Yield: $0.10 \mathrm{~g}$, 57\%. Anal. Calcd for $\mathrm{C}_{60} \mathrm{H}_{56} \mathrm{~N}_{12} \mathrm{~B}_{2} \mathrm{Ru}$. $\mathrm{CH}_{2} \mathrm{Cl}_{2}$ : C, 63.55; H, 5.07; N, 14.58. Found: C, 63.49; H, 5.16, N, 14.37 . IR: $\nu(\mathrm{BH}) 2477 \mathrm{~cm}^{-1}(\mathrm{~m}), \nu(\mathrm{C}=\mathrm{C}) 1543 \mathrm{~cm}^{-1}(\mathrm{~m}) .{ }^{1} \mathrm{H}$ NMR $\left(500 \mathrm{MHz}, \mathrm{CD}_{2} \mathrm{Cl}_{2}, 233 \mathrm{~K}\right): \delta 2.44,2.68\left(\mathrm{~s}, 3 \mathrm{H}\right.$ each, $\left.\mathrm{NCH}_{3}\right), 4.29,4.64$ $\left(\mathrm{d},{ }^{2} \mathrm{~J}(\mathrm{HH})=13.8 \mathrm{~Hz}, 1 \mathrm{H}\right.$ each, $\left.\mathrm{CH}_{a} H_{\mathrm{b}}\right), 6.06(\mathrm{~s}, 1 \mathrm{H}, \mathrm{CH}=$ $\left.\mathrm{C}\left(\mathrm{C}_{6} \mathrm{H}_{5}\right)_{2}\right), 6.13,6.18,6.37,6.50,7.63,7.86,7.88,7.97(\mathrm{~s} \mathrm{br}, 1 \mathrm{H}$ each, $\mathrm{Tp}), 6.30,7.91,8.68\left(\mathrm{~s} \mathrm{br}, 1 \mathrm{H}\right.$ each, $\left.\mathrm{C}_{3} \mathrm{H}_{3} \mathrm{~N}_{2}\right), 6.51,6.58,6.60,6.79(\mathrm{~s} \mathrm{br}$, $1 \mathrm{H}$ each, $\mathrm{CH}=\mathrm{CH}), 6.22,6.25,6.65,6.92,7.34,7.47,8.09(\mathrm{~m} \mathrm{br}, 10 \mathrm{H}$, $\left.\mathrm{C}_{6} \mathrm{H}_{5}\right) .{ }^{13} \mathrm{C}\left\{{ }^{1} \mathrm{H}\right\}$ NMR $\left(125 \mathrm{MHz}, \mathrm{CD}_{2} \mathrm{Cl}_{2}, 233 \mathrm{~K}\right): \delta 35.9,36.2$ $\left(\mathrm{NCH}_{3}\right), 61.5\left(\mathrm{CH}_{2}\right), 104.7,105.2,106.3,133.4,135.4,136.1,139.5$, 144.9, $148.5(\mathrm{Tp}), 105.0,136.2,145.9\left(\mathrm{C}_{3} \mathrm{H}_{3} \mathrm{~N}_{2}\right), 118.8,122.0,122.9$, $123.0(\mathrm{CH}=\mathrm{CH}), 109.5,126.9,127.5,127.6,128.5\left(\mathrm{C}_{6} \mathrm{H}_{5}\right), 138.1$ $\left(=\mathrm{C}\left(\mathrm{C}_{6} \mathrm{H}_{5}\right)_{2}\right), 140.6\left(\mathrm{Ru}=\mathrm{C}\left(\mathrm{C}_{3} \mathrm{H}_{3} \mathrm{~N}_{2}\right) \mathrm{CH}\right), 180.2,183.5(\mathrm{RuC})$, $283.3\left(\mathrm{Ru}=\mathrm{C}\left(\mathrm{C}_{3} \mathrm{H}_{3} \mathrm{~N}_{2}\right) \mathrm{CH}\right)$.

$\left[\mathrm{TpRu}=\mathrm{C}\left(\mathrm{N}\left(\mathrm{CH}_{2}\right)_{4} \mathrm{CH}_{2}\right) \mathrm{CH}=\mathrm{CPh}_{2}(\mathrm{~L})\right]\left[\mathrm{BPh}_{4}\right]$ (8). To a solution of the allenylidene complex $6(0.15 \mathrm{~g}, 0.15 \mathrm{mmol})$ in dichloromethane $(8 \mathrm{~mL})$ was added piperidine $(20 \mu \mathrm{L}, 0.2 \mathrm{mmol})$. The mixture was stirred at room temperature for $18 \mathrm{~h}$. An orange-brown solution was obtained. The solvent was removed in vacuo, and the residue was washed thoroughly with petroleum ether and dried in vacuo. Recrystallization from 1,2-dichloroethane/petroleum ether afforded red-orange needles of $\mathbf{8}$ containing half of a solvate molecule of dichloroethane. The crystals were filtered off and dried in vacuo. Yield: $0.58 \mathrm{~g}, 57 \%$. Anal. Calcd for $\mathrm{C}_{62} \mathrm{H}_{63} \mathrm{~N}_{11} \mathrm{~B}_{2} \mathrm{Ru} \cdot 0.5 \mathrm{C}_{2} \mathrm{H}_{4} \mathrm{Cl}_{2}: \mathrm{C}, 64.92 ; \mathrm{H}$, 5.61; N, 12.07. Found: C, 64.88; H, 5.74, N, 12.25. IR: $\nu(\mathrm{BH}) 2465 \mathrm{~cm}^{-1}(\mathrm{~m})$. ${ }^{1} \mathrm{H}$ NMR $\left(500 \mathrm{MHz}, \mathrm{CD}_{2} \mathrm{Cl}_{2}, 298 \mathrm{~K}\right): \delta 0.37,1.29,1.42,3.33,3.45$,
3.87, $4.18\left(\mathrm{~m}, 10 \mathrm{H}, \mathrm{N}\left(\mathrm{CH}_{2}\right)_{4} \mathrm{CH}_{2}\right), 2.12,2.50$ (s, $3 \mathrm{H}$ each, $\left.\mathrm{NCH}_{3}\right)$, $5.01,5.17\left(\mathrm{~d},{ }^{2} \mathrm{~J}(\mathrm{HH})=13.2 \mathrm{~Hz}, 1 \mathrm{H}\right.$ each, $\left.\mathrm{CH}_{a} \mathrm{H}_{\mathrm{b}}\right), 5.78\left(\mathrm{~d},{ }^{3} \mathrm{~J}(\mathrm{HH})=2\right.$ $\mathrm{Hz}, 1 \mathrm{H}), 5.99\left(\mathrm{t},{ }^{3} \mathrm{~J}(\mathrm{HH})=2.2 \mathrm{~Hz}, 1 \mathrm{H}\right), 6.05\left(\mathrm{t},{ }^{3} \mathrm{~J}(\mathrm{HH})=2.2 \mathrm{~Hz}, 1 \mathrm{H}\right)$, $6.42\left(\mathrm{t},{ }^{3} \mathrm{~J}(\mathrm{HH})=2.1 \mathrm{~Hz}, 1 \mathrm{H}\right), 7.76\left(\mathrm{~d},{ }^{3} \mathrm{~J}(\mathrm{HH})=2 \mathrm{~Hz}, 1 \mathrm{H}\right), 7.80$ $\left(\mathrm{d},{ }^{3} \mathrm{~J}(\mathrm{HH})=2.3 \mathrm{~Hz}, 1 \mathrm{H}\right), 7.83\left(\mathrm{~d},{ }^{3} J(\mathrm{HH})=2.2 \mathrm{~Hz}, 1 \mathrm{H}\right), 7.96(\mathrm{~d}$, $\left.{ }^{3} J(\mathrm{HH})=2.4 \mathrm{~Hz}, 1 \mathrm{H}\right)(\mathrm{Tp}), 6.22\left(\mathrm{~s}, 1 \mathrm{H}, \mathrm{CH}=\mathrm{C}\left(\mathrm{C}_{6} \mathrm{H}_{5}\right)_{2}\right), 6.58,6.71$, $6.78,6.79\left(\mathrm{~d},{ }^{3} \mathrm{~J}(\mathrm{HH})=2 \mathrm{~Hz}, 1 \mathrm{H}\right.$ each, $\left.\mathrm{CH}=\mathrm{CH}\right), 6.80,6.40,7.02,7.22$ $\left(\mathrm{m}, 10 \mathrm{H}, \mathrm{C}_{6} \mathrm{H}_{5}\right) .{ }^{13} \mathrm{C}\left\{{ }^{1} \mathrm{H}\right\} \mathrm{NMR}\left(125 \mathrm{MHz}, \mathrm{CD}_{2} \mathrm{Cl}_{2}, 298 \mathrm{~K}\right): \delta 25.2$, 26.8, 27.8, 56.3, 58.8 $\left({\mathrm{N}\left(\mathrm{CH}_{2}\right)_{4}} \mathrm{CH}_{2}\right), 36.8,37.1\left(\mathrm{NCH}_{3}\right), 63.3\left(\mathrm{CH}_{2}\right)$, 106.1, 107.0, 107.6, 136.5, 137.5, 138.3, 142.8, 146.6, 147.1 (Tp), 121.8, 122.3, 124.0, $124.7(\mathrm{CH}=\mathrm{CH}), 136.0\left(\mathrm{Ru}=\mathrm{C}\left(\mathrm{N}_{\left(\mathrm{CH}_{2}\right)_{4}} \mathrm{CH}_{2}\right) \mathrm{CH}\right)$, $128.5,129.1,130.1,131.1\left(C_{6} \mathrm{H}_{5}\right), 189.1,192.6(\mathrm{RuC}), 259.3(\mathrm{Ru}=$ $\left.\mathrm{C}\left(\mathrm{N}\left(\mathrm{CH}_{2}\right)_{4} \mathrm{CH}_{2}\right) \mathrm{CH}\right)$.

$\left[\mathrm{TpRu}=\mathrm{C}(\mathrm{X}) \mathrm{CH}=\mathrm{CPh}_{2}(\mathrm{~L})\right]\left[\mathrm{BPh}_{4}\right]\left(\mathrm{X}=\mathrm{SC}_{5} \mathrm{H}_{4} \mathrm{~N}(9), \mathrm{SC}_{6} \mathrm{H}_{4} \mathrm{SH}\right.$ (10)). To a solution of the allenylidene complex $6(0.15 \mathrm{~g}, 0.15 \mathrm{mmol})$ in 1,2-dichloroethane $(8 \mathrm{~mL})$ was added 2-pyridinethiol $(22 \mathrm{mg}, 0.2 \mathrm{mmol})$ or 1,3-benzenedithiol $(28 \mathrm{mg}, 0.2 \mathrm{mmol})$. The mixture was stirred at $80{ }^{\circ} \mathrm{C}$ for $18 \mathrm{~h}$. After a transitory brown color, a dark green solution was obtained. The solvent was removed in vacuo, and the residue was washed thoroughly with petroleum ether and dried in vacuo. Recrystallization from 1,2-dichloroethane/petroleum ether afforded green crystals, which were filtered off and dried in vacuo. Data for 9 are as follows. Yield: 0.095 g, 57\%. Anal. Calcd for $\mathrm{C}_{62} \mathrm{H}_{57} \mathrm{~N}_{11} \mathrm{~B}_{2} \mathrm{RuS}$ : C, 67.03; H, 5.17; N, 13.87. Found: C, 66.85; H, 5.26, N, 13.69. IR: $\nu(\mathrm{BH}) 2480 \mathrm{~cm}^{-1}(\mathrm{~m})$, $\nu(\mathrm{C}=\mathrm{C}) 1570 \mathrm{~cm}^{-1}(\mathrm{~m}) .{ }^{1} \mathrm{H}$ NMR $\left(500 \mathrm{MHz}, \mathrm{CD}_{2} \mathrm{Cl}_{2}, 298 \mathrm{~K}\right): \delta 2.43$, $2.78\left(\mathrm{~s}, 3 \mathrm{H}\right.$ each, $\left.\mathrm{NCH}_{3}\right), 5.31,6.07\left(\mathrm{~d},{ }^{2} \mathrm{~J}(\mathrm{HH})=13.8 \mathrm{~Hz}, 1 \mathrm{H}\right.$ each, $\left.\mathrm{CH}_{a} \mathrm{H}_{\mathrm{b}}\right), 6.16\left(\mathrm{~s}, 1 \mathrm{H}, \mathrm{CH}=\mathrm{C}\left(\mathrm{C}_{6} \mathrm{H}_{5}\right)_{2}\right), 6.11,6.21,6.33,6.50,7.82,7.95$, 7.99, 8.67 (s br, $1 \mathrm{H}$ each, Tp), 6.24, 7.15, 7.32, 8.68 (m, $1 \mathrm{H}$ each, $\left.\mathrm{SC}_{5} \mathrm{H}_{4} \mathrm{~N}\right), 6.64,6.77,6.81,6.86(\mathrm{~s} \mathrm{br}, 1 \mathrm{H}$ each, $\mathrm{CH}=\mathrm{CH}), 5.68,6.57$, $7.07\left(\mathrm{~m}, 10 \mathrm{H}, \mathrm{C}_{6} \mathrm{H}_{5}\right) .{ }^{13} \mathrm{C}\left\{{ }^{1} \mathrm{H}\right\} \mathrm{NMR}\left(125 \mathrm{MHz}, \mathrm{CD}_{2} \mathrm{Cl}_{2}, 298 \mathrm{~K}\right): \delta 36.4$, $36.8\left(\mathrm{NCH}_{3}\right), 63.2\left(\mathrm{CH}_{2}\right), 105.9,106.1,106.9,136.2,136.6,136.8,143.9$, 145.0, $145.3(\mathrm{Tp}), 123.1,125.9,128.5,150.3,157.9\left(\mathrm{SC}_{5} \mathrm{H}_{4} \mathrm{~N}\right), 121.7$, $121.9,123.3,123.7(\mathrm{CH}=\mathrm{CH}), 125.7,126.3,130.6,143.1\left(\mathrm{C}_{6} \mathrm{H}_{5}\right), 138.4$ $\left(=\mathrm{C}\left(\mathrm{C}_{6} \mathrm{H}_{5}\right)_{2}\right), 141.2\left(\mathrm{Ru}=\mathrm{C}\left(\mathrm{SC}_{5} \mathrm{H}_{4} \mathrm{~N}\right) \mathrm{CH}\right), 181.1,182.7(\mathrm{RuC}), 315.5$ $\left(\mathrm{Ru}=\mathrm{C}\left(\mathrm{SC}_{5} \mathrm{H}_{4} \mathrm{~N}\right) \mathrm{CH}\right)$. Data for 10 are as follows. Yield: $0.12 \mathrm{~g}, 60 \%$. Anal. Calcd for $\mathrm{C}_{63} \mathrm{H}_{58} \mathrm{~N}_{10} \mathrm{~B}_{2} \mathrm{RuS}_{2} \cdot \mathrm{C}_{2} \mathrm{H}_{4} \mathrm{Cl}_{2}: \mathrm{C}$, 64.65; H, 5.20; N, 10.62 . Found: C, 64.79; H, 5.26, N, 10.78. IR: $\nu(\mathrm{BH}) 2488 \mathrm{~cm}^{-1}(\mathrm{~m}), \nu(\mathrm{C}=\mathrm{C})$ $1570 \mathrm{~cm}^{-1}(\mathrm{~m}) .{ }^{1} \mathrm{H}$ NMR $\left(500 \mathrm{MHz}, \mathrm{CD}_{2} \mathrm{Cl}_{2}, 298 \mathrm{~K}\right): \delta 2.39,2.76(\mathrm{~s}, 3 \mathrm{H}$ each, $\left.\mathrm{NCH}_{3}\right), 3.55(\mathrm{~s}, 1 \mathrm{H}, \mathrm{SH}), 5.45\left(\mathrm{~m}, 2 \mathrm{H}, \mathrm{CH}_{a} \mathrm{H}_{\mathrm{b}}\right), 6.17(\mathrm{~s}, 1 \mathrm{H}$, $\left.\mathrm{CH}=\mathrm{C}\left(\mathrm{C}_{6} \mathrm{H}_{5}\right)_{2}\right), 6.13,6.16,6.20,6.55,7.83,7.96,8.04,8.83(\mathrm{~s} \mathrm{br}, 1 \mathrm{H}$ each, $\mathrm{Tp}$ ), 6.60, 6.74, 6.76, 6.83 ( $\mathrm{s}$ br, $1 \mathrm{H}$ each, $\mathrm{CH}=\mathrm{CH}$ ), 5.59, 6.43, 6.55, 6.70, 6.99, 7.15, 7.36, $7.48\left(\mathrm{~m}, 14 \mathrm{H}, \mathrm{C}_{6} \mathrm{H}_{5}+\mathrm{SC}_{6} \mathrm{H}_{4} \mathrm{SH}\right) .{ }^{13} \mathrm{C}\left\{{ }^{1} \mathrm{H}\right\}$ NMR $\left(125 \mathrm{MHz}, \mathrm{CD}_{2} \mathrm{Cl}_{2}, 298 \mathrm{~K}\right): \delta 36.1,36.6\left(\mathrm{NCH}_{3}\right), 62.6\left(\mathrm{CH}_{2}\right)$, 105.4, 105.8, 106.5, 136.0, 137.0, 137.6, 142.1, 142.7, 144.7 (Tp), 121.1, 121.4, 122.5, $123.0(\mathrm{CH}=\mathrm{CH}), 125.5,127.1,128.0,128.3,128.8,129.9$, 130.8, 132.0, 132.3, 133.0, $134.9\left(\mathrm{C}_{6} \mathrm{H}_{5}+\mathrm{SC}_{6} \mathrm{H}_{4} \mathrm{SH}\right), 137.5(=$ $\left.\mathrm{C}\left(\mathrm{C}_{6} \mathrm{H}_{5}\right)_{2}\right), 140.6\left(\mathrm{Ru}=\mathrm{C}\left(\mathrm{SC}_{6} \mathrm{H}_{4} \mathrm{SH}\right) \mathrm{CH}\right), 180.3,181.9(\mathrm{RuC}), 315.0$ $\left(\mathrm{Ru}=\mathrm{C}\left(\mathrm{SC}_{6} \mathrm{H}_{4} \mathrm{SH}\right) \mathrm{CH}\right)$.

[TpRuC $\left.\equiv \mathrm{CC}\left(\mathrm{CH}_{2} \mathrm{COCH}_{3}\right) \mathrm{Ph}_{2}(\mathrm{~L})\right]$ (11). To a mixture of the allenylidene complex $7(0.2 \mathrm{~g}, 0.2 \mathrm{mmol})$ and an excess of solid $\mathrm{KOBu}^{\mathrm{t}}(0.1 \mathrm{~g})$ was added acetone $(8 \mathrm{~mL})$. An immediate color change from deep purple to orange-brown was observed. The mixture was stirred at room temperature for $15 \mathrm{~min}$. The solvent was removed in vacuo, and the residue was washed with petroleum ether. The solids were extracted with toluene, and the solution was filtered through Celite. Removal of the solvent in vacuo afforded a golden yellow microcrystalline material, which was washed with petroleum ether and dried in vacuo. Yield: 0.13 g, $86 \%$. Anal. Calcd for $\mathrm{C}_{36} \mathrm{H}_{37} \mathrm{~N}_{10} \mathrm{BORu}$ : C, 58.62; H, 5.06; N, 18.99. Found: C, 58.47; H, 4.89, N, 18.70. IR: $\nu(B H) 2455 \mathrm{~cm}^{-1}(\mathrm{~m})$, $\nu(\mathrm{C} \equiv \mathrm{C}) 2061 \mathrm{~cm}^{-1}(\mathrm{~s}), \nu(\mathrm{C}=\mathrm{O}) 1695 \mathrm{~cm}^{-1}(\mathrm{~s}), \nu(\mathrm{C}=\mathrm{C}) 1665 \mathrm{~cm}^{-1}$ (m). ${ }^{1} \mathrm{H}$ NMR $\left(500 \mathrm{MHz}, \mathrm{C}_{6} \mathrm{D}_{6}, 298 \mathrm{~K}\right): \delta 1.94\left(\mathrm{~s}, 3 \mathrm{H}, \mathrm{CH}_{2} \mathrm{COCH}_{3}\right)$, $2.29\left(\mathrm{~s}, 6 \mathrm{H}, \mathrm{NCH}_{3}\right), 3.37\left(\mathrm{~s}, 2 \mathrm{H}, \mathrm{CH}_{2} \mathrm{COCH}_{3}\right), 4.49,7.41\left(\mathrm{~d},{ }^{2} \mathrm{~J}(\mathrm{HH})=\right.$ $11.7 \mathrm{~Hz}, 1 \mathrm{H}$ each, $\left.\mathrm{CH}_{a} H_{\mathrm{b}}\right), 5.75\left(\mathrm{t},{ }^{3} \mathrm{~J}(\mathrm{HH})=2.3 \mathrm{~Hz}, 1 \mathrm{H}\right), 6.00(\mathrm{t}$, $\left.{ }^{3} J(\mathrm{HH})=2 \mathrm{~Hz}, 2 \mathrm{H}\right), 6.28\left(\mathrm{~d},{ }^{3} J(\mathrm{HH})=2 \mathrm{~Hz}, 1 \mathrm{H}\right), 7.11(\mathrm{br}, 1 \mathrm{H}), 7.62$ $\left(\mathrm{d},{ }^{3} \mathrm{~J}(\mathrm{HH})=2.3 \mathrm{~Hz}, 2 \mathrm{H}\right), 8.01\left(\mathrm{~d},{ }^{3} J(\mathrm{HH})=1.8 \mathrm{~Hz}, 2 \mathrm{H}\right)(\mathrm{Tp}), 6.28$, $5.96\left(\mathrm{~d},{ }^{3} \mathrm{~J}(\mathrm{HH})=2 \mathrm{~Hz}, 2 \mathrm{H}\right.$ each, $\left.\mathrm{CH}=\mathrm{CH}\right), 6.95,7.06,7.82(\mathrm{~m}, 10 \mathrm{H}$, $\left.\mathrm{C}_{6} \mathrm{H}_{5}\right) .{ }^{13} \mathrm{C}\left\{{ }^{1} \mathrm{H}\right\} \mathrm{NMR}\left(125 \mathrm{MHz}, \mathrm{C}_{6} \mathrm{D}_{6}, 298 \mathrm{~K}\right): \delta 31.6\left(\mathrm{CH}_{2} \mathrm{COCH}_{3}\right)$, $35.5\left(\mathrm{NCH}_{3}\right), 50.2(\mathrm{C} \equiv \mathrm{C}-\mathrm{C}), 57.8\left(\mathrm{CH}_{2} \mathrm{COCH}_{3}\right), 63.5\left(\mathrm{CH}_{2}\right), 104.8$, 
104.9, 134.1, 134.4, 142.1, 144.8 (Tp), $108.1(\mathrm{RuC} \equiv \mathrm{C}-\mathrm{C}), 118.8,120.2$ $(\mathrm{CH}=\mathrm{CH}), 125.5,127.8,128.4,149.9\left(\mathrm{C}_{6} \mathrm{H}_{5}\right), 129.3(\mathrm{RuC} \equiv \mathrm{C}-\mathrm{C})$, $198.8(\mathrm{RuC}), 207.7(\mathrm{C}=\mathrm{O})$.

Kinetic Study of the Reaction of Substitution of Dinitrogen in 2 by $\mathrm{CD}_{3} \mathrm{CN}$. Samples of 2 in $\mathrm{CD}_{3} \mathrm{CN}$ were immersed into a liquid $\mathrm{N}_{2} /$ ethanol bath, to "freeze" the substitution reaction during transport and handling. The sample was removed from the bath and inserted into the probe of the NMR spectrometer at $298 \mathrm{~K}$. Once shims were adjusted, the probe was warmed to the desired temperature. The NMR temperature controller was previously calibrated against a methanol sample, the reproducibility being $\pm 0.5^{\circ} \mathrm{C} .{ }^{1} \mathrm{H}$ NMR spectra were recorded for at least 3 half-lives at regular intervals using the spectrometer software for accurate time control. Peak intensities were analyzed from stacked plots of the ${ }^{1} \mathrm{H}$ NMR spectra. First-order rate constants were derived from the least-squares best-fit lines of the $\ln$ (intensity) versus time plots. The uncertainty in the isomerization rate constants represents 1 standard deviation $( \pm \sigma)$ derived from the slope of the best-fit line. Uncertainties in the activation enthalpies and entropies were calculated from the uncertainties in the slope and intercept of the best-fit lines of the Eyring plots.

Crystal Structure Analysis. Crystals of $\mathbf{2}$ and 7 suitable for X-ray structural determination were mounted on glass fibers and then transferred to a Bruker Smart APEX CCD three-circle diffractometer with a sealed-tube source and graphite-monochromated Mo $\mathrm{K} \alpha$ radiation $(\lambda=0.71073 \AA)$ at the Servicio Central de Ciencia y Tecnología de la Universidad de Cadiz. In each case, four sets of frames were recorded over a hemisphere of the reciprocal space by $\omega$ scans with $\delta(\omega)=0.30^{\circ}$ and an exposure of $10 \mathrm{~s}$ per frame. Correction for absorption was applied by scans of equivalents using the SADABS program. ${ }^{47}$ An insignificant crystal decay correction was also applied. The structures of $\mathbf{2}$ and 7 were solved by Patterson and direct methods, respectively. Both structures were refined on $F^{2}$ by full-matrix least squares (SHELX97) ${ }^{48}$ by using all unique data. All non-hydrogen atoms were refined anisotropically, except those of a disordered dichloromethane solvate in 7 , which was not modeled. The program ORTEP- $3^{49}$ was used for plotting. CCDC 1404689-1404690 contain supplementary crystallographic data for this paper. These data can be obtained free of charge from The Cambridge Crystallographic Data Centre via www.ccdc.cam.ac.uk/ data_request/cif.

\section{ASSOCIATED CONTENT}

\section{S Supporting Information}

The Supporting Information is available free of charge on the ACS Publications website at DOI: 10.1021/acs.organomet.5b00964.

Crystallographic data for compounds 2 and 7 (CIF) Crystal data and experimental details for the crystal structure determination, rate constants for the reaction of dinitrogen substitution in 2 by $\mathrm{CD}_{3} \mathrm{CN}$, and ${ }^{1} \mathrm{H}$ and ${ }^{13} \mathrm{C}\left\{{ }^{1} \mathrm{H}\right\}$ NMR spectra for compounds $\mathbf{1 - 1 1}$ and $\left[\mathrm{TpRu}\left(\mathrm{NCCD}_{3}\right)(\mathrm{L})\right]$ $\left[\mathrm{BAr}_{4}^{\prime}\right](\mathrm{PDF})$

\section{AUTHOR INFORMATION}

\section{Corresponding Authors}

*E-mail for M.J.-T.: manuel.tenorio@uca.es.

*E-mail for M.C.P.: carmen.puerta@uca.es.

Notes

The authors declare no competing financial interest.

\section{ACKNOWLEDGMENTS}

We wish to thank Dr. Miguel Angel Centeno, from the ICMSECSIC (Sevilla), for recording the Raman spectra and the Spanish Ministerio de Economia y Competitividad (Project CTQ201015390) and Junta de Andalucía (PAIDI FQM188) for financial support.

\section{REFERENCES}

(1) Detz, R. J.; Hiemstra, H.; van Maarseveen, J. H. Eur. J. Org. Chem. 2009, 2009, 6263-6276.

(2) Nishibayashi, Y. Synthesis 2012, 2012, 489-503.

(3) (a) Nishibayashi, Y.; Wakiji, I.; Hidai, M. J. Am. Chem. Soc. 2000, 122, 11019-11020. (b) Nishibayashi, Y.; Wakiji, I.; Ishii, Y.; Uemura, S.; Hidai, M. J. Am. Chem. Soc. 2001, 123, 3393-3394. (c) Nishibayashi, Y.; Inada, Y.; Hidai, M.; Uemura, S. J. Am. Chem. Soc. 2002, 124, 79007901. (d) Nishibayashi, Y.; Yoshikawa, M.; Inada, Y.; Hidai, M.; Uemura, S. J. Am. Chem. Soc. 2002, 124, 11846-11847. (e) Nishibayashi, Y.; Milton, M. D.; Inada, Y.; Yoshikawa, M.; Wakiji, I.; Hidai, M.; Uemura, S. Chem. - Eur. J. 2005, 11, 1433-1451. (g) Nishibayashi, Y.; Shinoda, A.; Miyake, Y.; Matsuzawa, H.; Sato, M. Angew. Chem., Int. Ed. 2006, 45, 4835-4839. (h) Yada, Y.; Miyake, Y.; Nishibayashi, Y. Organometallics 2008, 27, 3614-3617.

(4) (a) Inada, Y.; Nishibayashi, Y.; Hidai, M.; Uemura, S. J. Am. Chem. Soc. 2002, 124, 15172-15173. (b) Ammal, S. C.; Yoshikai, N.; Inada, Y.; Nishibayashi, Y.; Nakamura, E. J. Am. Chem. Soc. 2005, 127, 9428-9438.

(5) (a) Nishibayashi, Y.; Onodera, G.; Inada, Y.; Hidai, M.; Uemura, S. Organometallics 2003, 22, 873-876. (b) Inada, Y.; Nishibayashi, Y.; Uemura, S. Angew. Chem., Int. Ed. 2005, 44, 7715-7717. (c) Kanao, K.; Tanabe, Y.; Miyake, Y.; Nishibayashi, Y. Organometallics 2010, 29, 2381-2384.

(6) Kondo, T.; Kanda, Y.; Baba, A.; Fukuda, K.; Nakamura, A.; Wada, K.; Morisaki, Y.; Mitsudo, T. J. Am. Chem. Soc. 2002, 124, 12960-12961.

(7) Cadierno, V.; Díez, J.; García-Garrido, S. E.; Gimeno, J. Chem. Commun. 2004, 2716-2717.

(8) Cadierno, V.; Gimeno, J. Chem. Rev. 2009, 109, 3512-3560.

(9) Bruneau, C.; Dixneuf, P. H. Angew. Chem., Int. Ed. 2006, 45, 21762203.

(10) Metal Vinylidenes and Allenylidenes in Catalysis: From Reactivity to Applications in Synthesis; Bruneau, C., Dixneuf, P. H., Eds.; Wiley-VCH: Weinheim, Germany, 2008.

(11) (a) Bernad, D. J.; Esteruelas, M.; López, A. M.; Oliván, M.; Oñate, E.; Puerta, M. C.; Valerga, P. Organometallics 2000, 19, 4327-4335. (b) Bernad, D. J.; Esteruelas, M.; López, A. M.; Modrego, J.; Puerta, M. C.; Valerga, P. Organometallics 1999, 18, 4995-5003. (c) Esteruelas, M.; Gómez, A. V.; López, A. M.; Oñate, E. Organometallics 1998, 17, 35673573. (d) Esteruelas, M.; Gómez, A. V.; López, A. M.; Modrego, J.; Oñate, E. Organometallics 1997, 16, 5826-5835.

(12) (a) García de la Arada, I.; Díez, J.; Gamasa, M. P.; Lastra, E. Organometallics 2015, 34, 1345-1353. (b) Strinitz, F.; Tucher, J.; Januszewski, J. A.; Waterloo, A. R.; Stegner, P.; Förtsch, S.; Hübner, E.; Tykwinski, R. R.; Burzlaff, N. Organometallics 2014, 33, 5129-5144. (c) Kopf, H.; Holzberger, B.; Pietraszuk, C.; Hübner, E.; Burzlaff, N. Organometallics 2008, 27, 5894-5905. (d) Cadierno, V.; Gamasa, M. P.; Gimeno, J. Coord. Chem. Rev. 2004, 248, 1627-1657. (e) Cadierno, V.; Gamasa, M. P.; Gimeno, J.; Borge, J.; García-Granda, S. Organometallics 1997, 16, 3178-3187.

(13) (a) Hyder, I.; Jiménez-Tenorio, M.; Puerta, M. C.; Valerga, P. Organometallics 2011, 30, 726-737. (b) Bustelo, E.; Jiménez-Tenorio, M.; Puerta, M. C.; Valerga, P. Organometallics 2007, 26, 4300-4309. (c) Jiménez-Tenorio, M.; Palacios, M. D.; Puerta, M. C.; Valerga, P. J. Organomet. Chem. 2004, 689, 2776-2785.

(14) (a) Pavlik, S.; Mereiter, K.; Puchberger, M.; Kirchner, K. J. Organomet. Chem. 2005, 690, 5497-5507. (b) Beach, N. J.; Williamson, A. E.; Spivak, G. J. J. Organomet. Chem. 2005, 690, 4640-4647. (c) Beach, N. J.; Jenkins, H. A.; Spivak, G. J. Organometallics 2003, 22, 5179-5181. (d) Rigaut, S.; Touchard, D.; Dixneuf, P. H. Organometallics 2003, 22, 3980-3984.

(15) (a) Pino-Chamorro, J. A.; Bustelo, E.; Puerta, M. C.; Valerga, P. Organometallics 2009, 28, 1546-1557. (b) Bustelo, E.; JiménezTenorio, M.; Puerta, M. C.; Valerga, P. Organometallics 2006, 25, 4019-4025. (c) Bustelo, E.; Jiménez-Tenorio, M.; Puerta, M. C.; Valerga, P.; Mereiter, K. Organometallics 2002, 21, 1903-1911.

(16) (a) Aneetha, H.; Jiménez-Tenorio, M.; Puerta, M. C.; Valerga, P.; Mereiter, K. Organometallics 2003, 22, 2001-2013. (b) Bustelo, E.; Jiménez-Tenorio, M.; Puerta, M. C.; Valerga, P. Eur. J. Inorg. Chem. 2001, 2001, 2391-2398. (c) Bustelo, E.; Jiménez-Tenorio, M.; Puerta, 
M. C.; Valerga, P. Organometallics 1999, 18, 4563-4573. (d) de los Ríos, I.; Jiménez-Tenorio, M.; Puerta, M. C.; Valerga, P. J. Organomet. Chem. 1997, 549, 221-232. (e) Jiménez-Tenorio, M. A.; Jiménez-Tenorio, M.; Puerta, M. C.; Valerga, P. Organometallics 1997, 16, 5528-5535.

(17) (a) Bolaño, S.; Rodríguez-Rocha, M.-M.; Bravo, J.; Castro, J.; Oñate, E.; Peruzzini, M. Organometallics 2009, 28, 6020-6030. (b) Bolaño, S.; Rodríguez-Rocha, M.-M.; Bravo, J.; Castro, J. Eur. J. Inorg. Chem. 2010, 2010, 663-663. (c) Pavlik, S.; Mereiter, K.; Puchberger, M.; Kirchner, K. Organometallics 2005, 24, 3561-3575. (d) Buriez, B.; Burns, I. D.; Hill, A. F.; White, A. J. P.; Williams, D. J.; Wilton-Ely, J. D. E. T. Organometallics 1999, 18, 1504-1516. (e) Buriez, B.; Cook, D. J.; Harlow, K. J.; Hill, A. F.; Welton, T.; White, A. J. P.; Williams, D. J.; Wilton-Ely, J. D. E. T. J. Organomet. Chem. 1999, 578, 264-267.

(18) (a) Selegue, J. P. Organometallics 1982, 1, 217-218. (b) Selegue, J. P.; Young, B. A.; Logan, S. L. Organometallics 1991, 10, 1972-1980. (c) Bruce, M. I.; Low, P. J.; Tiekink, E. R. T. J. Organomet. Chem. 1999, 572, 3-10. (d) Byrne, L. T.; Koutsantonis, G. A.; Sanford, V.; Selegue, J. P.; Schauer, P. A.; Iyer, R. S. I. Organometallics 2010, 29, 1199-1209.

(19) (a) Cadierno, V.; Gamasa, M. P.; Gimeno, J.; Perez-Carreño, E.; García-Granda, S. J. Organomet. Chem. 2003, 670, 75-83. (b) Cadierno, V.; Conejero, S.; Gamasa, M. P.; Gimeno, J.; Falvello, L. R.; Llusar, R. M. Organometallics 2002, 21, 3716-3726. (c) Cadierno, V.; Díez, J.; Gamasa, M. P.; Gimeno, J.; Lastra, E. Coord. Chem. Rev. 1999, 193-195, 147-205.

(20) (a) Jiménez-Tenorio, M.; Puerta, M. C.; Valerga, P.; Mereiter, K. J. Am. Chem. Soc. 2000, 122, 11230-11231. (b) Aneetha, H.; JiménezTenorio, M.; Puerta, M. C.; Valerga, P.; Sapunov, V. N.; Schmid, R.; Kirchner, K.; Mereiter, K. Organometallics 2002, 21, 5334-5346.

(21) (a) Fürstner, A.; Liebl, M.; Lehmann, C. W.; Picquet, M.; Kunz, R.; Bruneau, C.; Touchard, D.; Dixneuf, P. H. Chem. - Eur. J. 2000, 6, 1847-1857. (b) Ulrich, K.; Porhiel, E.; Péron, V.; Ferrand, V.; Le Bozec, H. J. Organomet. Chem. 2000, 601, 78-86. (c) Pilette, D.; Ouzzine, K.; Le Bozec, H.; Dixneuf, P. H.; Rickard, C. E. F.; Roper, W. R. Organometallics 1992, 11, 809-817.

(22) (a) Jafarpour, L.; Huang, J.; Stevens, E. D.; Nolan, S. P. Organometallics 1999, 18, 3760-3763. (b) Schanz, H.-J.; Jafarpour, L.; Stevens, E. D.; Nolan, S. P. Organometallics 1999, 18, 5187-5190.

(23) Opstal, T.; Verpoort, F. Polym. Bull. (Heidelberg, Ger.) 2003, 50, $17-23$.

(24) Ledoux, N.; Drozdzak, R.; Allaert, B.; Linden, A.; Van Der Voort, P.; Verpoort, F. Dalton Trans. 2007, 5201-5210.

(25) Ledoux, N.; Allaert, B.; Schaubroeck, D.; Monsaert, S.; Drozdzak, R; Van Der Voort, P.; Verpoort, F. J. Organomet. Chem. 2006, 691, 5482-5486.

(26) Lozano-Vila, A. M.; Monsaert, S.; Bajek, A.; Verpoort, F. Chem. Rev. 2010, 110, 4865-4909.

(27) Fernández, F. E.; Puerta, M. C.; Valerga, P. Inorg. Chem. 2013, 52, 4396-4410.

(28) Fernández, F. E.; Puerta, M. C.; Valerga, P. Inorg. Chem. 2013, 52, 6502-6509.

(29) (a) Sanford, M. S.; Love, J. A.; Grubbs, R. H. Organometallics 2001, 20, 5314-5318. (b) Burtscher, D.; Perner, B.; Mereiter, K.; Slugovc, C. J. Organomet. Chem. 2006, 691, 5423-5430.

(30) Albrecht, M.; Miecznikowski, J. R.; Samuel, A.; Faller, J. W.; Crabtree, R. H. Organometallics 2002, 21, 3596-3604.

(31) (a) Poyatos, M.; Mata, J. A.; Peris, E. Chem. Rev. 2009, 109, 36773707. (b) Mata, J. A.; Poyatos, M.; Peris, E. Coord. Chem. Rev. 2007, 251, 841-859.

(32) Fernández, F. E.; Puerta, M. C.; Valerga, P. Organometallics 2011, 30, 5793-5802.

(33) Poyatos, M.; Mas-Marzá, E.; Sanaú, M.; Peris, E. Inorg. Chem. 2004, 43, 1793-1798.

(34) (a) Tubaro, C.; Bertinazzo, D.; Monticelli, M.; Saoncella, O.; Volpe, A.; Basato, M.; Badocco, D.; Pastore, P.; Graiff, C.; Venzo, A. Eur. J. Inorg. Chem. 2014, 2014, 1524-1532. (b) Lai, Y.-B.; Lee, C.-S.; Lin, W.-J.; Naziruddin, A. R.; Hwang, W.-S. Polyhedron 2013, 53, 243-248.

(35) Aneetha, H.; Jimenez-Tenorio, M.; Puerta, M. C.; Valerga, P.; Mereiter, K. Organometallics 2002, 21, 628-635.
(36) (a) Tanabe, Y.; Kuriyama, S.; Arashiba, K.; Nakajima, K.; Nishibayashi, Y. Organometallics 2014, 33, 5295-5300. (b) Bennett, M. A.; Byrnes, M. J.; Chung, G.; Edwards, A. J.; Willis, A. C. Inorg. Chim. Acta 2005, 358, 1692-1708. (c) Zhang, J.; Gandelman, M.; Shimon, L. J. W.; Rozenberg, H.; Milstein, D. Organometallics 2004, 23, 40264033.

(37) Handbook of Chemistry and Physics, 76th ed.; Lide, R. D., Ed.; CRC Press: New York, 1995; Section 9, p 20.

(38) (a) Wieder, N. L.; Gallagher, M.; Carroll, P. J.; Berry, D. H. J. Am. Chem. Soc. 2010, 132, 4107-4109. (b) Gallagher, M.; Wieder, N. L.; Dioumaev, V. K.; Carroll, P. J.; Berry, D. H. Organometallics 2010, 29, 591-603. (c) Field, L. D.; Guest, R. W.; Vuong, K. Q.; Dalgarno, S. J.; Jensen, P. Inorg. Chem. 2009, 48, 2246-2253. (d) Aneetha, H.; JimenezTenorio, M.; Puerta, M. C.; Valerga, P.; Mereiter, K. Organometallics 2003, 22, 1779-1782. (e) Jiménez-Tenorio, M. A.; Jiménez-Tenorio, M.; Puerta, M. C.; Valerga, P. J. Chem. Soc., Dalton Trans. 1998, 36013608.

(39) Belt, S. T.; Scaiano, J. C.; Whittlesey, M. K. J.Am. Chem. Soc. 1993, 115, 1921-1935.

(40) Ben Said, R.; Hussein, K.; Tangour, B.; Sabo-Etienne, S.; Barthelat, J.-C. J. Organomet. Chem. 2003, 673, 56-66.

(41) (a) Tanaka, H.; Arashiba, K.; Kuriyama, S.; Sasada, A.; Nakajima, K.; Yoshizawa, K.; Nishibayashi, Y. Nat. Commun. 2014, 5, 3737. (b) Arashiba, K.; Miyake, Y.; Nishibayashi, Y. Nat. Chem. 2011, 3 (2), $120-125$.

(42) Blacquiere, J. M.; Higman, C. S.; Gorelsky, S. I.; Beach, N. J.; Dalgarno, S. J.; Fogg, D. E. Angew. Chem., Int. Ed. 2011, 50, 916-919.

(43) Volland, M. A. O.; Hansen, S. M.; Rominger, F.; Hofmann, P. Organometallics 2004, 23, 800-816.

(44) Macías-Arce, I.; Puerta, M. C.; Valerga, P. Eur. J. Inorg. Chem. 2010, 2010, 1767-1776.

(45) (a) Cadierno, V.; Gimeno, J.; Gamasa, M. P. Eur. J. Inorg. Chem. 2001, 2001, 571-591. (b) Esteruelas, M. A.; Gómez, A. V.; López, A. M.; Modrego, J.; Oñate, E. Organometallics 1998, 17, 5434-5436. (c) Cadierno, V.; Gamasa, M. P.; Gimeno, J.; López-González, M. C.; Borge, J.; García-Granda, S. Organometallics 1997, 16, 4453-4463.

(46) Jiménez-Tenorio, M.; Puerta, M. C.; Valerga, P. Organometallics 2015, 34, 1001-1004.

(47) Sheldrick, G. M. SADABS, 2001 version; University of Göttingen, Göttingen, Germany, 2001.

(48) (a) Sheldrick, G. M. SHELXTL version 6.10, Crystal Structure Analysis Package; Bruker AXS, Madison, WI, 2000. (b) Sheldrick, G. M. Acta Crystallogr., Sect. A: Found. Crystallogr. 2008, 64, 112-122.

(49) ORTEP-3 for Windows, version 1.076: Farrugia, L. J. J. Appl. Crystallogr. 1997, 30, 565. 